\title{
How well does sticky information explain inflation and output inertia?
}

Citation for published version (APA):

Carrillo, J. A. (2010). How well does sticky information explain inflation and output inertia? METEOR, Maastricht University School of Business and Economics. METEOR Research Memorandum No. 018 https://doi.org/10.26481/umamet.2010018

Document status and date:

Published: 01/01/2010

DOI:

10.26481/umamet.2010018

Document Version:

Publisher's PDF, also known as Version of record

\section{Please check the document version of this publication:}

- A submitted manuscript is the version of the article upon submission and before peer-review. There can be important differences between the submitted version and the official published version of record.

People interested in the research are advised to contact the author for the final version of the publication, or visit the DOI to the publisher's website.

- The final author version and the galley proof are versions of the publication after peer review.

- The final published version features the final layout of the paper including the volume, issue and page numbers.

Link to publication

\footnotetext{
General rights rights.

- You may freely distribute the URL identifying the publication in the public portal. please follow below link for the End User Agreement:

www.umlib.nl/taverne-license

Take down policy

If you believe that this document breaches copyright please contact us at:

repository@maastrichtuniversity.nl

providing details and we will investigate your claim.
}

Copyright and moral rights for the publications made accessible in the public portal are retained by the authors and/or other copyright owners and it is a condition of accessing publications that users recognise and abide by the legal requirements associated with these

- Users may download and print one copy of any publication from the public portal for the purpose of private study or research.

- You may not further distribute the material or use it for any profit-making activity or commercial gain

If the publication is distributed under the terms of Article $25 \mathrm{fa}$ of the Dutch Copyright Act, indicated by the "Taverne" license above, 


\title{
Maastricht University
}

\author{
Julio A. Carrillo \\ How Well Does Sticky \\ I nformation Explain I nflation \\ and Output I nertia?
}

$\mathrm{RM} / 10 / 018$

\section{METEOR}

Maastricht University School of Business and Economics

Maastricht Research School of Economics

of Technology and Organization

P.O. Box 616

NL - 6200 MD Maastricht

The Netherlands 


\title{
How Well Does Sticky Information Explain Inflation and Output Inertia?
}

\author{
Julio A. Carrillo* \\ Maastricht University, School of Business and Economics
}

February 8, 2010

\begin{abstract}
This paper compares two approaches that aim to explain the lagged and persistent behavior of inflation and output after a variation in the interest rate. Two variants that produce inertia are added to a baseline DSGE model of sticky prices: 1) a lagged inflation indexation rule along with habit formation; and 2) sticky information applied to firms, workers, and households. The rival models are then confronted to a monetary SVAR using U.S. data in order to estimate the rates of inflation indexation, habit formation, price rigidities, information stickiness, and the monetary policy rule parameters. It is shown that the sticky information model has a modest advantage at fitting inflation than the lagged inflation index. model with habits. For output, the opposite is true. These differences are consistent in the robustness analysis, but they are not big enough to imply a significant statistical difference in terms of the goodness of fit of each model. In addition, the results suggest that sticky information may replace entirely sticky prices as a explanation of price setting behavior, but the latter might not apply to wages. Finally, the analysis find that information stickiness should be pervasive (i.e., applied to households, firms, and workers) in order to replicate the responses of aggregate variables to a shock in monetary policy.
\end{abstract}

Keywords: Inflation and output persistence, sticky prices, sticky information

JEL Class.: E31, E52, C15

*Address: Maastricht University (ALGEC), A0.05a, PoBox 616, MD6200 Maastricht, The Netherlands. Email: j.carrillo@maastrichtuniversity.nl. I thank to Sanvi Avouyi-Dovi, Bertrand Candelon, Martial Dupaigne, Patrick Fève, Lenard Lieb, Joan Muysken, Céline Poilly, Raf Wouters, seminar participants at the 2008 North American Summer Meeting of the Econometric Society at Carnegie Mellon University, and the 2008 Latin American Meetings of the Econometric Society at Fundaçao Getulio Vargas for helpful comments. This piece of work has been greatly benefited by past and present collaborations with Julian Matheron, Patrick Fève, and Lenard Lieb; thanks for your help. All remaining errors are, of course, my own. 


\section{Introduction}

In the last 20 years, a large volume of the monetary economics literature has focus on explaining the effects of monetary policy on inflation and output dynamics. A few of the findings are the are listed as follows: first, output and inflation take a few quarters to react to a variation in the nominal interest rate; and second, the reaction of inflation is lagging behind the reaction of output. These stylized facts have been documented in several studies, such as Christiano et al. (1999, 2005) for the U.S., Mojon and Peersman (2003) and Sousa and Zaghini (2008) for Europe, and Wang and Wen (2007) for several OECD countries.

Fuhrer and Moore (1995) and Chari, Kehoe, and McGrattan (2000) have documented the inability of pure sticky-price models in replicating the aforementioned regularities. As a result, dynamic, stochastic general equilibrium (DSGE) models have followed two main strategies to explain the observed delayed responses to monetary policy. On the one hand, the works of Galí and Gertler (1999) inspired the inclusion of a lagged inflation-indexation rule for those firms and workers who might find themselves unable to reoptimize their prices and wages in a certain period. For output, it is normally assumed that households form habits in their consumption patterns, along with other real rigidities on investment. These devices have proved to be successful at replicating the inertia of inflation and output after a shock to monetary policy (see Christiano et al., 2005; Boivin and Giannoni, 2006; or Smets and Wouters, 2007). On the other hand, the work of Mankiw and Reis (2002) has popularized the view that these ad hoc devices may be replaced by environments in which information flows slowly throughout the population.

The aim of this paper is to confront these two main strands of the literature in terms of their predicted effects after a shock to monetary policy and to ask which one delivers a better fit in terms of the dynamics responses of inflation and output. There are several papers that tackle a similar question, such as Andrés, López-Salido and Nelson (2005), Knotek (2006), Korenok and Swanson (2007), Kiley (2007), Trabandt (2007), Wang and Wen (2007), Dupor et al. (2009), Coibion and Gorodnichenko (2009), Coibion (2010), among others. The answers of these authors are mixed, as are their analytical methods. Some find that a sticky price model with lagged inflation indexation and habits performs better than a pure sticky information model. Some others argue that a model containing both sticky prices and sticky information performs better in terms of inflation. Some papers focus only on the fit of the Phillips curve, while others pay attention to the aggregate dynamics coming from a general equilibrium approach. Remarkably, all of these papers only consider the case of inattentive firms while assuming that workers and consumers have full information. 
Mankiw and Reis (2006) argue, in contrast, that a pervasive slow diffusion of information (or that all agents are subject to information frictions) is a necessary feature of the model to fit different moments of the data. ${ }^{1}$ At least to my knowledge, only the works of Mankiw and Reis (2006, 2007), and Reis (2009) consider inattentive firms, workers, and households. Nevertheless, these studies do not compare the performance of the pervasive sticky information model to a standard model with sticky prices and lagged inflation indexation as well as habits.

The contribution of the present paper is threefold. First, it studies the case of a model allowing for nominal rigidities and pervasive information stickiness, i.e. dual-stickiness, and it compares it to the case of nominal rigidities with lagged inflation indexation and habits. Second, by allowing a dual-stickiness model, the paper asks whether the data support the coexistence between sticky information and sticky prices, or whether the former may entirely replace the latter. And third, the paper provides further evidence of the necessity of having pervasive information stickiness in order to explain the persistent responses of inflation and output to a shock in monetary policy.

In contrast with previous studies, the present analysis focuses directly on the dynamic responses of a set of macroeconomic variables to a shock in monetary policy, which are estimated with a monetary SVAR using U.S. data for the period 1960(1)-2007(2). The approach employed herein follows the Minimum Distance Estimation (MDE) proposed by Rotemberg and Woodford (1997) and used extensively in papers by Altig et al. (2005), Christiano et al. (2005), Boivin and Giannoni (2006), and others. The purpose is to match some selected model-based impulse response functions (IRFs) with their empirical SVAR counterparts in order to estimate the parameters that create persistence and hump-shaped patterns in each of the model economies. Here, the selected variables are output, inflation, wage inflation, and the target interest rate. The advantage of this technique over a single-equation analysis is that it obtains information from the entire economic structure of the model economy, which dynamics can be analyzed for different response horizons.

The strategy of the analysis is as follows. First, a baseline model containing price and wage rigidities is assumed. Then, in the first variant, a lagged inflation-indexation rule for firms and workers is added, along with habit formation for households. The second variant adds sticky information to firms, workers, and households. Therefore, both variants share similar preferences, technology, and a potential role for nominal rigidities. Second, the IRFs of each variant are used in the MDE estimation in order to find the parameters that are mainly responsible for the aggregate dynamics in each model. These parameters refer to the degree of inflation indexation,

\footnotetext{
${ }^{1}$ These moments are the following: 1) Inflation tend to rise jointly with output during booms; 2) Real wages are smoother than output; and 3 Real variables respond gradually to macroeconomic shocks.
} 
habit formation, rates of updating information, rates of price and wage reoptimization, and the parameters of the monetary policy rule. The estimation procedure involves a bootstrapping method that aims to provide critical values for statistical inference and which allows one to screen possible problems of identification. The later is also useful to assess the goodness of fit of each model by computing the bootstrapped distribution of the root-mean-squared error (RMSE) concerning the fit of each model variant. Finally, a robustness analysis is performed, assuming different calibrations, output gap measures, and an alternative ordering in the SVAR.

The results are as follows. First, the sticky information model is slightly better than the lagged inflation-indexation model with respect to inflation, while for output, the opposite is true. These differences, although consistent throughout the robustness analysis, do not seem to be statically significant in terms of the RMSE statistic. In terms of the dynamics of wage inflation and the nominal interest rate, both models do equally well. Also, a remarkable finding, is that the estimated parameters of the monetary policy rule are quite similar in both models. Second, the estimated version of the sticky information model suggests that inattentive firms may replace entirely sticky prices as an explanation of price setting behavior. The latter is consistent with the findings of Bils and Klenow (2004) and Klenow and Willis (2007), who use microdata to argue that individual prices are in a way flexible, but they react to old information. For wages, the conclusion is less robust. Although the sticky information model estimates the degree of wage rigidities equal to zero, the large scope of its confidence interval does not allow the conclusion that wages are allowed to move (be reoptimized) each period. This finding might presume a problem of weakly identification concerning wage rigidities in the sticky information model. And third, the assumption that only firms are inattentive, while workers and households have full information, is completely rejected by the data. In addition, assuming that either firms or workers are attentive and thus that information stickiness is not pervasive, results in a poor goodness of fit of the model. This finding suggests that the best environment to study sticky information models is the one in which all type of agents face information frictions.

The rest of the paper is as follows. Section 2 describes the baseline model with nominal and real rigidities, and adds indexation and habits, or sticky information. Section 3 details the econometric approach. Section 4 and 5 discusses the estimation results and perform a robustness analysis. Section 6 discusses some dimensions that might help to discriminate between one of the two models. Finally, some concluding remarks are offered. 


\section{Model variants}

The model presented below shares several common features when compared to the state-of-art literature, such as Christiano, Eichenbaum, and Evans (2005), Smets and Wouters (2007), or Mankiw and Reis (2007).

\subsection{The baseline}

\subsubsection{Final good sector}

A perfectly competitive firm produces a homogenous good, $d_{t}$, that can be either consumed, $y_{t}$, or be used as a production input in the intermediate-good sector, $q_{t}$. Aggregate demand for the homogenous good is thus given by $d_{t}=y_{t}+q_{t}$. The firm produces $d_{t}$ by combining a continuum of intermediate goods, indexed by $\varsigma \in[0,1]$, using the technology suggested by Kimball (1995), and used by Eichenbaum and Fisher (2004) or Woodford (2003):

$$
\int_{0}^{1} G\left(\frac{d_{t}(\varsigma)}{d_{t}}\right) \mathrm{d} \varsigma=1
$$

where $G(\cdot)$ is a increasing and strictly concave function, that satisfies the normalization $G(1)=1$; $d_{t}(\varsigma)$ is the input of intermediate good $\varsigma$. The standard Dixit-Stiglitz specification is contained in Kimball's technology by setting $G(z)=z^{\left(\theta_{p}-1\right) / \theta_{p}}$, with $z=d(\varsigma) / d$ and $\theta_{p}>1$ as the elasticity of substitution among input goods. The general form used by Kimball offers some advantages, as having a variable $\theta_{p}$, which, as it will be noted below, constitutes a source of strategic complementarities among intermediate-good producers. In this context, $\theta_{p}(z) \equiv-\frac{z G^{\prime}(z)}{G^{\prime \prime}(z)}$.

The aggregate good firm chooses $d_{t}$ and $d_{t}(\varsigma)$ to maximize its profits

$$
P_{t} d_{t}-\int_{0}^{1} P_{t}(\varsigma) d_{t}(\varsigma)
$$

subject to (1), where $P_{t}$ and $P_{t}(\varsigma)$ are the nominal price of the aggregate good and the intermediate input $\varsigma$, respectively. The demand for input $d_{t}(\varsigma)$ is thus given by:

$$
d_{t}(\varsigma)=d_{t} G^{\prime-1}\left(\frac{P_{t}(\varsigma)}{P_{t}} \lambda_{t}\right)
$$

where $\lambda_{t}=\int_{0}^{1} G\left(d_{t}(u) / d_{t}\right) \cdot\left(d_{t}(u) / d_{t}\right) \mathrm{d} u$, and $G^{\prime-1}$ represents the inverse function of $G^{\prime}$. The general price index, $P_{t}$, is implicitly determined by the zero profits condition of the aggregate goof firm.

\subsubsection{Intermediate good}

Each intermediate good $d_{t}(\varsigma)$ is produced by a single monopolistic firm. Rotemberg and Woodford (1995) propose a gross-output production function of the form

$$
d_{t}(\varsigma)=\min \left\{\frac{F\left(n_{t}(\varsigma)\right)}{1-s_{q}}, \frac{q_{t}(\varsigma)}{s_{q}}\right\},
$$


where $F(\cdot)$ is an increasing and concave function, $n_{t}(\varsigma)$ is the composite labor input, to be defined later, $q_{t}(\varsigma)$ are raw materials employed by firm $\varsigma$, and $s_{q} \in[0,1]$ determines the coefficients of input requirements. The convenience of considering raw materials in this fixed-proportions technology relies on the sources of strategic complementarities (see below) that this device implements. The real cost function is thus denoted by $S\left(d_{t}(\varsigma)\right)=w_{t} F^{-1}\left(d_{t}(\varsigma)\left(1-s_{q}\right)\right)+s_{q} d_{t}(\varsigma)$, where $w_{t} \equiv W_{t} / P_{t}$ denotes aggregate real wages.

Monopolistic firms face nominal rigidities, as it is assumed that in each and every period prices can be reoptimized with a fixed probability $1-\alpha_{p}$. If firm $\varsigma$ is unable to re-optimize in period $T$, then its price is updated according to a rule-of-thumb of the form $P_{T}(\varsigma)=\left(1+\delta_{t, T}^{p}\right) P_{t}(\varsigma)$, where $t<T$ denotes the period that the last reoptimization took place. The term $\left(1+\delta_{t, T}^{p}\right)$ will be properly defined once the two inertia environments that this paper analyzes, namely lagged inflation indexation and sticky information, are described.

Let $P_{t}^{\star}(\varsigma)$ denote the price of firm $\varsigma$ if it is allowed to reoptimize in period $t$, and $d_{t, T}^{\star}(\varsigma)$ the time $T$ output of this firm. Therefore $P_{t}^{\star}(\varsigma)$ is chosen in order to maximize the present discounted sum of profit streams, based on firm s's available information, i.e.,

$$
\begin{gathered}
\max _{P_{t}(\varsigma)} \mathrm{E}_{\Gamma_{t}(\varsigma)} \sum_{T=t}^{\infty}\left(\beta \alpha_{p}\right)^{T-t} \varphi_{T}\left[\left(\frac{\left(1+\delta_{t, T}^{p}\right) P_{t}(\varsigma)}{P_{T}}\right) d_{t, T}^{\star}(\varsigma)-S\left(d_{t, T}^{\star}(\varsigma)\right)\right] \\
\text { subject to } d_{t, T}^{\star}(\varsigma)=d_{t} G^{\prime-1}\left(\frac{\left(1+\delta_{t, T}^{p}\right) P_{t}(\varsigma)}{P_{T}} \lambda_{T}\right)
\end{gathered}
$$

where $\beta^{T-t} \varphi_{T}$ is the stochastic discount factor, and $\mathrm{E}_{\Gamma_{t}(\varsigma)}$ represents the expectations operator conditional to the information contained in the set $\Gamma_{t}(\varsigma)$.

\subsubsection{Households}

Households are composed of two agents: a consumer and a worker. The former chooses consumption and bond holdings, while the latter uses his monopolistic power to set his wage, as it is assumed that every worker has a unique labor type. As a result, labor is traded in specific labor markets. Also, we allow consumers and workers to differ in the information they possess to make their decisions. This assumption is a model device that may give flexibility to match wage inflation and output inertia with higher accuracy. ${ }^{2}$ On the other hand, it could be argued that the information needed for wagesetting might be highly influenced for specific structures, such as unions, whereas consumers are not influenced by the same factors.

\footnotetext{
${ }^{2}$ See Mankiw and Reis (2006) and (2007).
} 
All households earn utility from consumption and leisure, which is represented by the instantaneous utility function

$$
U\left(g\left(c_{t}(v), c_{t-1}(v)\right)\right)-V\left(h_{t}(\varpi)\right)
$$

Consumer types and worker types are indexed by $v$ and $\varpi$, respectively, in the $[0,1]$ interval; $c_{t}(v)$ and $h_{t}(\varpi)$ denote consumption and labor; $U$ is increasing and concave; $V$ is increasing and convex; and, finally, $g$ is a function that may allow for the existence of habit formation in consumption. The time $t$ budget constraint of the household, in real terms, is given by:

$$
c_{t}(v)+\frac{b_{t}(v)}{1+i_{t}}+\tau_{t}(v) \leq \frac{W_{t}(\varpi)}{P_{t}} h_{t}(\varpi)+\frac{b_{t-1}(v)}{1+\pi_{t}}+\operatorname{div}_{t}
$$

where $b_{t}(v)$ denotes real bonds acquired in period $t$ and maturing in period $t+1 ; i_{t}$ is the nominal interest rate; $\tau_{t}(v)$ denotes real lump-sum government transfers as well as state-contingent securities that ensure that all households begin with the same wealth at time $t ;^{3} W_{t}(\varpi)$ is the nominal wage rate earned by type- $\varpi$ labor; and $\operatorname{div}_{t}$ represents real profits redistributed by monopolistic firms. Consumers choose a plan for current and future consumption and real bond holdings in order to maximize

$$
\mathrm{E}_{\Upsilon_{t}(v)} \sum_{T=t}^{\infty} \beta^{T-t} U\left(g\left(c_{T}(v), c_{T-1}(v)\right)\right)
$$

subject to (4) and no-Ponzi schemes. $\beta \in(0,1)$ is the subjective discount factor and $\mathrm{E}_{\Upsilon_{t}(v)}$ represents the expectations operator conditional to the information set $\Upsilon_{t}(v)$.

Workers sell their labor input to a perfect competitive labor intermediary. The latter produces a single labor input using a Dixit-Stiglitz aggregator. Because the worker is a monopolist supplier, he will take into account the labor intermediary's demand when setting his wage. Additionally, the worker faces wage rigidities, as he might not always be able to reoptimize its wage. As in the case of intermediate producers, it is assumed that in each and every period wages can be reoptimized with a fixed probability $1-\alpha_{w}$. If worker $\varpi$ is unable to reoptimize in period $T$, then its wage is updated according to a rule-of-thumb of the form $W_{T}(\varpi)=\left(1+\delta_{t, T}^{w}\right) W_{t}(\varpi)$, where $t<T$ denotes the period of the last reoptimization. Let $W_{t}^{\star}(\varpi)$ denote the wage of worker $\varpi$ if it is allowed to reoptimize in period $t$, and let $h_{t, T}^{\star}(\varpi)$ denote its time $T$ labor input. Therefore, $W_{t}^{\star}(\varpi)$ is chosen in order to maximize

$$
\mathrm{E}_{\Omega_{t}(\varpi)} \sum_{T=t}^{\infty} \beta^{T-t}\left[\Lambda_{T}(v) \frac{\left(1+\delta_{t, T}^{w}\right) W_{t}^{\star}(\varpi)}{W_{T}} h_{t, T}^{\star}(\varpi)-V\left(h_{t, T}^{\star}(\varpi)\right)\right]
$$

\footnotetext{
${ }^{3}$ The literature in the field points out that, in principle, households might be different with respect to consumption and asset holdings, as they can work different amounts and charge different wage rates. As Woodford (1996) and Erceg et al. (2000) show, adding this assumption ensures that, in equilibrium, households are homogenous in consumption and asset holdings.
} 


$$
\text { subject to } h_{t, T}^{\star}(\varpi)=\left(\frac{\left(1+\delta_{t, T}^{w}\right) W_{t}^{\star}(\varsigma)}{W_{T}}\right)^{-\theta_{w}} h_{T} .
$$

where $h_{t}$ is the aggregate labor input, $\theta_{w}>1$ is the elasticity of substitution among different labor types, $\Lambda_{t}(v)$ is the type-v's marginal utility of wealth, and $\mathrm{E}_{\Omega_{t}(\varpi)}$ is the expectations operator conditional to the information set $\Omega_{t}(\varpi)$.

\subsubsection{Government and Equilibrium}

There is no active role for the fiscal authority, while the central bank follows a typical Taylor rule of the form

$$
\begin{aligned}
\hat{\imath}_{t} & =a_{\pi} \hat{\pi}_{t}+a_{y} \hat{y}_{t}+e_{t} \\
e_{t} & =\rho_{e} e_{t-1}+\sigma_{\nu} \nu_{t} .
\end{aligned}
$$

where $\pi_{t}$ is the inflation rate of period $t, \rho_{e} \in[0,1), \sigma_{\nu}>0$, and $\nu_{t}$ is an iid random variable with mean zero and unitary variance. The monetary policy is shown in terms of percentage deviation from the steady state. It delivers interest-rate inertia from persistent shocks from the baseline rule, denoted by $e_{t}$, which consists of the discretionary part of monetary policy. Although it is not a general case, real determinacy is often achieved in this environment when $a_{\pi}>1$, which is an assumption that we follow closely when computing the dynamics of the model.

The equilibrium of this economy is characterized by a set of prices $\left\{P_{t}, P_{t}(\varsigma), W_{t}, W_{t}(\varpi), i_{t}\right\}$ and a set of quantities $\left\{d_{t}, q_{t}, y_{t}, c_{t}(v), b_{t}(v), n_{t}(\varsigma), h_{t}, h_{t}(\varpi)\right\}$, for all $\varsigma, v, \varpi$, such as all markets clear at all times. Notice that in equilibrium $y_{t}=\int_{0}^{1} c_{t}(v) \mathrm{d} v, h_{t}=\int_{0}^{1} n_{t}(\varsigma) \mathrm{d} \varsigma, \int_{0}^{1} b_{t}(v) \mathrm{d} v=0$, and $d_{t}=y_{t}+\int_{0}^{1} q_{t}(\varsigma) \mathrm{d} \varsigma{ }^{4}$

\subsection{Lagged inflation indexation and habit formation}

Sticky prices on their own are unable to bring inertia in inflation and output (see Fuhrer and Moore, 1995; Chari et al., 2000; or Fuhrer, 2006). For this reason, I consider two different devices that have proven to add this fundamental empirical characteristic in the baseline model. The first alternative assumes that firms and workers that were unable to re-optimize their prices and wages in period $T$ update them according to a rule-of-thumb of the form $X_{T}(\varrho)=\left(1+\delta_{t, T}^{x}\right) X_{t}(\varrho)$, for $X \in\{P, W\}$ and $\varrho \in\{\varsigma, \varpi\}$ where $t<T$ denotes the period of last re-optimization, and

$$
1+\delta_{t, T}^{x}= \begin{cases}\prod_{j=t}^{T-1}(1+\pi)^{1-\gamma_{x}^{b}}\left(1+\pi_{j}\right)^{\gamma_{x}^{b},} & \text { if } T>t \\ 1, & \text { otherwise. }\end{cases}
$$

\footnotetext{
${ }^{4}$ Notice that in equilibrium, the percentage deviations of aggregate consumption, aggregate raw materials, and aggregat demand are equal. That is, $\hat{y}_{t}=\hat{d}_{t}=\hat{q}_{t}$.
} 
where $\pi$ represents the steady state inflation, and $\gamma_{x}^{b} \in[0,1]$ for $x \in\{p, w\}$ measures the degree of indexation to past inflation values. When $\gamma_{p}^{b}=1$, then firms index their prices to reflect last period inflation and thus $P_{T}(\varsigma)=\left(1+\pi_{t-1}\right) P_{T-1}(\varsigma)$. The same logic is used for workers.

In the case of consumers, we allow for the existence of habit formation by setting

$$
g\left(c_{t}(v), c_{t-1}(v)\right)=c_{t}(v)-\gamma_{h}^{b} c_{t-1}(v)
$$

where $\gamma_{h}^{b} \in[0,1)$. In order to close the description of this environment, we need to make some assumptions about the information set of economic agents. The dynamics of the model should be consistent with the short-term restrictions that are used later in the empirical SVAR that identifies shocks in monetary policy. It is thus assumed that consumption, prices or wages do not react contemporaneously to innovations in the interest rate. In contrast, the demand for bonds does change as a result of policy innovations. We can justify this structure by assuming that the goods and labor markets open before the central bank makes a decision, while the financial market opens just after. As a result, $\Gamma_{t}(\varsigma)=\Upsilon_{t}(v)=\Omega_{t}(\varpi)=I_{t-1}$ for all $\varsigma, v$, $\varpi$ at the time consumption, prices and wages are decided, where $I_{t-1}$ reflect all available information concerning shocks and innovations up to time $t-1$. In contrast, $\Upsilon_{t}(v)=I_{t}$ when the demand for bonds is chosen. Because all types of agents share the same preferences and production technologies, all agents reoptimizing in period $t$ will choose the same values for their decision variables. We can thus drop type indexes and simply state that $P_{t}^{\star}(v)=P_{t}^{\star}, W_{t}^{\star}(v)=W_{t}^{\star}$, $\Lambda_{t}(v)=\Lambda_{t}$, and $c_{t}(v)=c_{t}=y_{t}$.

The dynamics of the model economy, stated as percentage deviations from the steady state, are described by the monetary rule contained in (5) and (6), plus the F.O.C. of consumption and bond holdings,

$$
\begin{aligned}
0 & =\tilde{\sigma} E_{t-1}\left\{\beta \gamma_{h}^{b} \hat{y}_{t+1}-\left[1+\beta\left(\gamma_{h}^{b}\right)^{2}\right] \hat{y}_{t}+\gamma_{h}^{b} \hat{y}_{t-1}\right\}-E_{t-1} \hat{\Lambda}_{t} \\
\hat{\Lambda}_{t} & =E_{t} \hat{\Lambda}_{t+1}+\left(\hat{\imath}_{t}-E_{t} \hat{\pi}_{t+1}\right),
\end{aligned}
$$

where $\hat{p}_{t}^{\star}=\hat{P}_{t}^{\star}-\hat{P}_{t} ; \hat{w}_{t}^{\star}=\hat{W}_{t}^{\star}-\hat{W}^{\prime} ; \beta_{x}=\beta \alpha_{x}$, with $x \in\{p, w\}$; and $\tilde{\sigma}=\frac{\sigma}{\left(1-\beta \gamma_{h}^{b}\right)\left(1-\gamma_{h}^{b}\right)}$ with $\sigma \equiv-\frac{U^{\prime \prime}(c) c}{U^{\prime}(c)}$ as the inverse of the elasticity of intertemporal substitution; plus the Phillips curves corresponding to prices and wages,

$$
\begin{aligned}
& \hat{p}_{t}^{\star}=E_{t-1}\left\{\left(1-\beta_{p}\right) \xi_{p}\left(\hat{w}_{t}+\omega_{p} \hat{y}_{t}\right)+\beta_{p}\left(\hat{p}_{t+1}^{\star}+\hat{\pi}_{t+1}-\gamma_{p}^{b} \hat{\pi}_{t}\right)\right\} \\
& \hat{w}_{t}^{\star}=E_{t-1}\left\{\left(1-\beta_{w}\right) \xi_{w}\left(\omega_{w} \phi \hat{Y}_{t}-\hat{\Lambda}_{t}-\hat{w}_{t}\right)+\beta_{w}\left(\hat{w}_{t+1}^{\star}+\hat{\pi}_{t+1}^{w}-\gamma_{w}^{b} \hat{\pi}_{t}\right)\right\},
\end{aligned}
$$

where $\omega_{p} \equiv-\frac{F^{\prime \prime}(n) n}{F^{\prime}(n)} \frac{F(n)}{F^{\prime}(n) n}$ is the elasticity of the marginal product of labor with regard to output; $\omega_{w}^{-1} \equiv \frac{V^{\prime}(h)}{V^{\prime \prime}(h) h}$ is the Frisch elasticity of labor supply; $\phi^{-1} \equiv \frac{F^{\prime}(n) n}{F(n)}$ is the elasticity of 
intermediate goods w.r.t to labor; finally, $\xi_{p}$ and $\xi_{w}$ include parameters governing the sources of real rigidities and strategic complementarities among price- and wage-setters, respectively. Specifically,

$$
\xi_{p}=\frac{1}{\theta_{p}(1) \omega_{p}+\left(1+\theta_{p}(1) \epsilon_{\mu}\right) /\left(1-\mu_{p}(1) s_{q}\right)}, \quad \text { and } \quad \xi_{w}=\frac{1}{\theta_{w} \omega_{w}+1} .
$$

The terms $\theta_{p}(1) \omega_{p}$ and $\theta_{w} \omega_{w}$ included in the above expressions are due to the assumption of specific factor markets, where $\theta_{p}(z)>1$ is the elasticity of demand of intermediate goods evaluated at $z \equiv d(\varsigma) / d=1$.

The parameter $\epsilon_{\mu} \equiv \mu_{p}^{\prime}(1) / \mu_{p}(1)$ indicates the elasticity of the desired intermediate producer markup, $\mu_{p}(z)$, evaluated at the steady state. If $\epsilon_{\mu}>0$ (and thus $\theta_{p}(z)$ is decreasing in $z$ ), a trade-off occurs among price setters who would like to cut their prices in order to increase their relative sales. As Kimball (1995) shows, if this increase leads to a less-elastic demand, then their desire markup will rise along with their marginal income. Therefore, in the presence of a decreasing demand elasticity, monopolistic suppliers would like to change their prices by less, as there is a compensation resulting from an increasing markup.

The term $\mu_{p}(1) s_{q}$ appears due to the input-output structure of the economy described by the gross-output production function introduced by Rotemberg and Woodford (1995). These authors argue that adding a share of primary factor inputs represents a closer approximation of real production technologies. The latter is of special importance in models where there is imperfect competition and prices do not co-move perfectly with marginal costs. Notably, a positive material goods share lowers the reaction of intermediate prices to movements in sales by decreasing the value of $\xi_{p}{ }^{5}$

In sum, the real rigidities described above might be useful to explain the lagged and persistent reaction of prices and wages observed after a shock in monetary policy. To conclude, the zeroprofit condition of the final-good producer and the labor intermediary imply that the percentage deviations of the general price and the nominal wage indexes can be written as

$$
\begin{aligned}
\hat{P}_{t} & =\left(1-\alpha_{p}\right) \hat{P}_{t}^{\star}+\alpha_{p} \hat{P}_{t-1}+\alpha_{p} \gamma_{p}^{b} \hat{\pi}_{t-1} \\
\hat{W}_{t} & =\left(1-\alpha_{w}\right) \hat{W}_{t}^{\star}+\alpha_{p} \hat{W}_{t-1}+\alpha_{w} \gamma_{w}^{b} \hat{\pi}_{t-1},
\end{aligned}
$$

while the steady-state percentage deviations of inflation and wage inflation are denoted by $\hat{\pi}_{t}=\hat{P}_{t}-\hat{P}_{t-1}$ and $\hat{\pi}_{t}^{w}=\hat{W}_{t}-\hat{W}_{t-1}$, respectively.

\footnotetext{
${ }^{5}$ For further insights about these sources of strategic complementarities, see Woodford (2003).
} 


\subsection{Pervasive information stickiness}

The second alternative to including inertia in the model consists of adding sticky information in households, firms, and workers. In this model variant, I assume that both kinds of stickiness, on information and on prices and wages, are present in the economy. The latter enable us to test whether the data support the coexistence of these two rigidities in the economy, which is a critical difference with the environments studied by Khan and Zhu (2006), Mankiw and Reis (2007), or Kiley (2008), among others. Therefore, sticky information only replaces inflation indexation and habit formation as a source for macroeconomic persistence.

In this economy, the rule-of-thumb that workers and firms use to update wages and prices in period $T$ takes the simple form $X_{T}(\varrho)=(1+\pi) X_{t}(\varrho)$, for $X \in\{P, W\}$ and $\varrho \in\{\varsigma, \varpi\}$ where $t<T$ denotes the period of the last reoptimization. That is, agents update their prices and wages according to steady-state inflation. Also, habit formation is not longer allowed for consumers, implying that $g\left(c_{t}(v), c_{t-1}(v)\right)=c_{t}(v)$. Consequently, the former statements assume that $\gamma_{w}^{b}, \gamma_{p}^{b}$, and $\gamma_{h}^{b}$ equal zero.

In contrast, the information structure is much more complex in this environment. Mankiw and Reis (2006) argue that a full-fledged DSGE model should present slow information diffusion pervasively, that is, that all agents in the economy face information frictions. It is thus assumed that at each and every period, every agent in the economy has a probability $1-\gamma_{x}^{s i}$ of collecting the newest information available, for $x \in\{p, w, h\}$ denoting prices, wages, and consumption, respectively. However, I maintain the assumption that consumption, prices, and wages are decided prior to the decision of the central bank, while financial markets open after. Therefore, a proportion $1-\gamma_{h}^{s i}$ of consumers decide their consumption bundles with the information contained in set $I_{t-1} ;\left(1-\gamma_{h}^{s i}\right) \gamma_{h}^{s i}$ use the information of set $I_{t-2} ;\left(1-\gamma_{h}^{s i}\right)\left(\gamma_{h}^{s i}\right)^{2}$ use the information contained in $I_{t-3}$, and so on. Naturally, a similar structure applies for workers and firms using their relevant updating information probabilities.

One complication that arises in sticky-information environments is that solving for the equilibrium dynamics requires taking into account the sequence of delayed expectations of endogenous variables, which in this case is infinite. Some authors, such as Trabandt (2007), solve the problem by truncating the number of lags present in expectations. Notice, however, that the structure of the model economy allows us to restrict our attention to the particular decisions of the most-informed agents. The reason is that all agents reoptimizing in period $t$ and sharing the same information will choose similar values for their decision variables, as all agents have similar preferences, production technologies, and access to financial markets. This property is 
especially useful when one wants to solve the model through undetermined coefficients.

Formally, if $X_{t}^{k}(\varrho)$ for $X \in\left\{c, P^{\star}, W^{\star}\right\}$ and $\varrho \in\{v, \varsigma, \varpi\}$ represent the optimal consumption, price or wage chosen by an agent with information set $I_{t-k}$, for $k \geq 1$, then, as a consequence of similar preferences and technologies, we can drop type indexes and simply state that $c_{t}^{k}=E_{t-k} c_{t}$, $P_{t}^{\star k}=E_{t-k} P_{t}^{\star}$, and $W_{t}^{\star k}=E_{t-k} W_{t}^{\star}$ for all $k>1$, where, by convention, we set $X_{t} \equiv X_{t}^{1}$ for $X \in\left\{c, P^{\star}, W^{\star}\right\}$. Therefore, the dynamics of this model economy, as stated in terms of the most informed agents and as percentage deviations from the steady state, are described by the monetary rule contained in (5) and (6), plus the F.O.C. of consumption and bond holdings of the most attentive consumer,

$$
\begin{gathered}
0=-\sigma E_{t-1} \hat{c}_{t}-E_{t-1} \hat{\Lambda}_{t} \\
\hat{\Lambda}_{t}=E_{t} \hat{\Lambda}_{t+1}+\left(\hat{\imath}_{t}-E_{t} \hat{\pi}_{t+1}\right),
\end{gathered}
$$

plus the Phillips curves of the most attentive firm and worker,

$$
\begin{aligned}
\hat{p}_{t}^{\star} & =E_{t-1}\left\{\left(1-\beta_{p}\right) \xi_{p}\left(\hat{w}_{t}+\omega_{p} \hat{Y}_{t}\right)+\beta_{p}\left(\hat{p}_{t+1}^{\star}+\hat{\pi}_{t+1}\right)\right\} \\
\hat{w}_{t}^{\star} & =E_{t-1}\left\{\left(1-\beta_{w}\right) \xi_{w}\left(\omega_{w} \phi \hat{Y}_{t}-\hat{\Lambda}_{t}-\hat{w}_{t}\right)+\beta_{w}\left(\hat{w}_{t+1}^{\star}+\hat{\pi}_{t+1}^{w}\right)\right\},
\end{aligned}
$$

where $\hat{p}_{t}^{\star}=\hat{P}_{t}^{\star}-\hat{P}_{t}$ and $\hat{w}_{t}^{\star}=\hat{W}_{t}^{\star}-\hat{W}_{t}$, plus the aggregate behavior of all consumers, price-, and wage-setters,

$$
\begin{aligned}
& \hat{y}_{t}=\left(1-\gamma_{h}^{s i}\right) \sum_{k=0}^{\infty}\left(\gamma_{h}^{s i}\right)^{k} E_{t-k-1} \hat{c}_{t} \\
& \hat{P}_{t}=\left(1-\alpha_{p}\right)\left(1-\gamma_{p}^{s i}\right) \sum_{k=0}^{\infty}\left(\gamma_{p}^{s i}\right)^{k} E_{t-k-1} \hat{P}_{t}^{\star}+\alpha_{p} \hat{P}_{t-1} \\
& \hat{W}_{t}=\left(1-\alpha_{w}\right)\left(1-\gamma_{w}^{s i}\right) \sum_{k=0}^{\infty}\left(\gamma_{w}^{s i}\right)^{k} E_{t-k-1} \hat{W}_{t}^{\star}+\alpha_{p} \hat{W}_{t-1} .
\end{aligned}
$$

The last three expressions are the components that add intrinsic inertia to the model economy. Also note that both sticky prices and sticky information coexist as long as $\alpha_{p}$ and $\gamma_{p}^{s i}$ are greater than zero. The equilibrium dynamics are solved using the algorithm employed by Lieb (2009), which is a refinement of the principles provided by Meyer-Ghode (2010). The approach employed by these authors is a method based on undetermined coefficients, which uses the infinite moving-average (MA) representation of the model economy.

\section{Econometric methodology}

This section details the monetary SVAR and the impulse response functions (IRFs) that will be used to estimate the two DSGE models described above. It also presents the minimum distance estimation (MDE) approach. 


\subsection{The Monetary SVAR and U.S. data}

The econometric analysis starts by characterizing the actual economy's response to a monetary policy shock. As it is common in the literature, this analysis can be done by estimating a monetary SVAR along the lines proposed by Christiano et al. $(1999,2005)$ or Boivin and Giannoni (2006). ${ }^{6}$ The details of this identification strategy are provided in the above papers. Here, the main ingredients are described. We consider a structural SVAR of the form:

$$
A_{0} Z_{t}=A_{1} Z_{t-1}+\cdots+A_{\ell} Z_{t-\ell}+\eta_{t}
$$

In order to identify the structural shocks to monetary policy $\nu_{t}$, a short-run identification strategy using a Cholesky decomposition can be employed. If so, the data vector $Z_{t}$ is decomposed according to $Z_{t}=\left(Z_{1, t}^{\prime}, \hat{\imath}_{t}, Z_{2, t}^{\prime}\right)^{\prime} . Z_{1, t}$ is a $n_{1} \times 1$ vector composed of variables that do not respond contemporaneously to the monetary shock $\nu_{t}$, and are thus assumed to be predetermined. In contrast, $Z_{2, t}$ is a $n_{2} \times 1$ vector containing variables that are allowed to respond contemporaneously to $\nu_{t}$.

The data used for the SVAR come from the U.S. Non-Farm Business sector over the sample period 1960(1)-2007(2). In addition to the federal funds rate, $\hat{\imath}_{t}$, the variables used for estimation are the output gap measured as the linearly detrended logarithm of GDP per capita, ${ }^{7} \hat{y}_{t}$, the quarterly growth rate of GDP's implicit price deflator, $\hat{\pi}_{t}$, and the quarterly growth rate of nominal hourly compensation, or wage inflation, $\hat{\pi}_{t}^{w}$. In addition, two "information" variables are included. First, the quarterly growth rate of the logarithm of the Commodity Research Bureau $(\mathrm{CRB})$ price index of sensitive commodities, $\hat{\pi}_{t}^{c}$, is considered to mitigate the so-called price puzzle. ${ }^{8}$ Second, the growth rate of M2, $\hat{\xi}_{t}$, is included to exploit some potential information involved in money growth. ${ }^{9}$ In order to implement the monetary policy shock's identification strategy outlined above, we set $Z_{1, t}=\left(\hat{y}_{t}, \hat{\pi}_{t}, \hat{\pi}_{t}^{w}, \hat{\pi}_{t}^{c}\right)^{\prime}$ and $Z_{2, t}=\hat{\xi}_{t}$. All time series are demeaned, such as they can be interpreted as percent deviations from their long-term equilibrium. The optimal lag length $\ell$ is determined by minimizing the Hannan-Quinn information criterion. In the empirical analysis, $\ell$ is found that be equal to 4 .

\footnotetext{
${ }^{6}$ See Christiano et al. (1996); and Rotemberg and Woodford (1997, 1999) for other examples of identifying strategies.

${ }^{7}$ The civilian, non-institutional population over 16 was used as a measure of population.

${ }^{8}$ This practice is a fairly standard in the literature. See Sims (1992), Eichenbaum (1992), Christiano et al. $(1996,1999)$.

${ }^{9}$ The data were extracted from the Bureau of Labor Statistics, the FREDII database, and the CRB.
} 


\subsection{Estimation strategy}

The model parameters are divided into two groups, $\psi_{1}$ and $\psi_{2}$. The first group is composed by parameters governing preferences, technology, and sources of strategic complementarity, i.e. $\psi_{1} \equiv\left\{\beta, \sigma, \theta_{p}, \theta_{w}, \omega_{p}, \omega_{w}, \epsilon_{\mu}, \phi, s_{q}\right\}$. $\beta$ is set equal to 0.99 , implying a steady-state annualized real interest rate of 4 per cent. We set $\sigma=\omega_{w}=1$, implying a logarithmic utility for consumption and a unitary Frisch labor supply elasticity, as considered by Altig et al. (2005) and Christiano et al. (2005). $\phi$ equals 1.33, denoting a steady-state share of labor income of 62.5 per cent, after correcting for the markup. If the intermediate firm production function is a Cobb-Douglas, then $\omega_{p}$ equals $\phi-1$. The share of material goods in gross output, $s_{q}$, is set to 50 per cent since it may represent a good approximation for the U.S. economy, as suggested by Rotemberg and Woodford (1995). We set $\theta_{p}=6$, following Rotemberg and Woodford (1997) and Christiano et al. (2005), which implies a price markup of 20 per cent. The markup elasticity to relative demand, $\epsilon_{\mu}$, is set to 1 , as used by Woodford (2003). Finally, $\theta_{w}$ is set to 21 as done by Christiano et al. (2005), implying a wage markup of 5 per cent.

The second group of model parameters includes the sources of intrinsic and extrinsic inertia carried out either by lagged inflation indexation or sticky information. It also includes the degree of price and wage rigidities as well as the parameters of the monetary policy rule and the policy shock; that is, $\psi_{2} \equiv\left\{\gamma_{p}, \gamma_{w}, \gamma_{h}, \alpha_{p}, \alpha_{w}, a_{\pi}, a_{y}, \rho_{e}, \sigma_{e}\right\}$. The partition between calibrated and estimating parameters responds to the difficulty that may be faced in identifying some parameters. For instance, estimating $\epsilon_{\mu}, \theta_{p}$, and $\alpha_{p}$ together (or, equivalently, $\theta_{w}$ and $\left.\alpha_{w}\right)$ raises issues in their identification, as these parameters appear in a single reduced-form coefficient in the Phillips curve. In terms of Canova and Sala (2009), the lack of reduced-form parameters raises the problem of partial identification. The latter has been noticed in practice by Rotemberg and Woodford (1997), Amato and Laubach (2003), or Eichenbaum and Fisher (2004). Nonetheless, the impact of different calibrations of these parameters is assessed in the robustness analysis. Other parameters, such as $\beta, \phi$, or $s_{q}$, are fixed in order to reflect aggregate values empirically observed in the data.

The parameters $\psi_{2}$ are estimated by minimizing a measure of the distance between the empirical responses of key aggregate variables and their model counterparts. ${ }^{10}$ More precisely, attention is focused on the responses of vector $X_{t}$, which is a subset of $Z_{t}$, and includes output, inflation, wage inflation, and the fed funds rate, that is, $X_{t}=\left(\hat{y}_{t}, \hat{\pi}_{t}, \hat{\pi}_{t}^{w}, \hat{\imath}_{t}\right)$. Define $h\left(\psi_{2}\right)$ as the mapping from $\psi_{2}$ to the model impulse response functions to a monetary shock. Next, let $\theta_{k}$ denote the vector of responses to a shock in monetary policy at horizon $k \geq 0$, as implied by the SVAR.

\footnotetext{
${ }^{10}$ See Rotemberg and Woodford (1997), Amato and Laubach (2003), Altig et al. (2005), Giannoni and Woodford (2004), Christiano et al. (2005), and Boivin and Giannoni (2006).
} 
Then, the object to match is $\theta=\operatorname{vec}\left(\left[\theta_{0}, \theta_{1}, \ldots, \theta_{K}\right]\right)^{\prime}$, where $K$ is the selected horizon. ${ }^{11}$ The estimate of $\psi_{2}$ is obtained by solving

$$
\hat{\psi}_{2}=\arg \min _{\psi_{2} \in \Psi} \mathcal{J}_{T}
$$

where

$$
\mathcal{J}_{T}=\left(h\left(\psi_{2}\right)-\hat{\theta}_{T}\right) V_{T}\left(h\left(\psi_{2}\right)-\hat{\theta}_{T}\right)^{\prime},
$$

$\Psi$ contains the admissible values for the parameters contained in $\psi_{2}, \hat{\theta}_{T}$ is an estimate of $\theta, T$ is the sample size, and $V_{T}$ is a diagonal matrix with the sample variances of $\theta$ along the diagonal. The choice of the weighting matrix has some specific advantages. As Christiano et al. (2005) note, it ensures that the model's impulse responses lie as much as possible within the confidence interval of the SVAR impulse responses. The disadvantage of using $V_{T}$ relies on the distribution properties of the $\mathcal{J}_{T}$ statistic. Becasue $V_{T}$ is not the optimal weighting matrix, it is quite probable that the asymptotic distribution of $\mathcal{J}_{T}$ will not be a $\chi^{2}$ with $\operatorname{dim}(\theta)$-dim $\left(\psi_{2}\right)$ degrees of freedom, under the null hypothesis that $\mathcal{J}_{T}$ equals zero (or that the model approximates perfectly the SVAR impulse responses). Fève et al. (2009) solve this problem using a bootstrapping method that computes the empirical distribution of $\mathcal{J}_{T}$, which enables one to test the null of $\mathcal{J}_{T}=0$. In the lines of Hall and Horowitz (1996), Fève et al.'s method proposes the generation of $N$ bootstrap samples of the SVAR and recomputes the relevant impulse responses. For each replication of impulse responses, set as $\theta^{i}$, the parameters contained in $\psi_{2}$ are re-estimated by solving

$$
\psi_{2}^{i}=\arg \min _{\psi_{2} \in \Psi} \mathcal{J}^{i}
$$

where

$$
\mathcal{J}^{i}=\left(h\left(\psi_{2}\right)-\theta^{i}-\hat{\mu}_{T}\right) V_{T}\left(h\left(\psi_{2}\right)-\theta^{i}-\hat{\mu}_{T}\right)^{\prime},
$$

and $\hat{\mu}_{T} \equiv h\left(\hat{\psi}_{2}\right)-\hat{\theta}_{T}$ is used to recenter the bootstrapped analog of the moment condition. Hall and Horowitz point out that, without recentering, the bootstrap could implement a moment condition that is not held in the bootstrapped sample. For instance, in the case of minimum distance estimation, not recentering may increase the probability of accepting the null hypothesis of $\mathcal{J}_{T}=0$, when it should be actually rejected. The method gives us the bootstrapped distribution of $\mathcal{J}^{i}$ that we can use for statistical inference. In the present analysis, $N$ is set to 1000.

The estimation method described above, as many others, can be subject to parameter identification issues, which in the case of the MDE estimation have been highlighted by Canova and Sala (2009). Even though the choice of the calibrated parameters tackles a well-identified problem of

\footnotetext{
${ }^{11}$ Because the model described embeds the same timing restrictions used for the SVAR, we can exclude from $\theta$ and $h\left(\psi_{2}\right)$ the elements of each response function that are zero by assumption.
} 
partial identification, we cannot rule out the possibility that some of the estimating parameters might encounter a problem of weak identification. One way to assess whether this possibility exists is by looking at the bootstrapped distribution of the estimating parameters, $\psi_{2}^{i}$, computed in equation 20. This distribution will give us an idea of how precisely are computed the estimating parameters, and whether we can use the distribution for inference purposes. Further, we can perform robustness exercises where not only the estimating parameters are subject to different calibrations, but also to a different measure of the output gap, or a different ordering of variables in the monetary SVAR.

\section{Empirical results}

\subsection{Responses of U.S. data to a monetary policy shock}

The impulse response functions of output, inflation, wage inflation, and the fed funds to a contractionary shock in monetary policy are reported in Figure 1, with $K=45$. The plain line is the SVAR's point estimates of the impulse responses, while the dash lines indicate the 90 per cent confidence interval, using Runkle (1987)'s bootstrap method with 10,000 replications.

These findings are in line with the results reported by Christiano et al. (1999, 2005), and other authors. Output exhibits a significant persistence and a hump-shaped pattern, peaking after six quarters. The response of inflation suggest a small, but insignificant, price-puzzle in the very short run. Inflation shows a hump-shaped profile, lagging behind output, and peaking during the third year after the shock. The response of wage inflation is qualitatively similar to inflation, although slightly lagging behind. Finally, the federal funds rate increases immediately and then gradually declines to the point where it eventually crosses the $x$-axis. The evidence provided by Christiano et al. $(1999,2005)$, replicated here, remains the most-cited reference characterizing two stylized facts of aggregate data: first, output and inflation take some quarters to respond to a variation in the interest rate; and second, the response of inflation lags behind the one of output. These features are those that the models described in Section 2 try to replicate. ${ }^{12}$

\subsection{Baseline estimations}

The baseline estimations for the lagged inflation indexation and the sticky price models are presented in the first row of tables 1 and 2, respectively. Accordingly, the $\mathcal{J}_{T}$ statistic shows that we cannot reject the null hypothesis that $\mathcal{J}_{T}=0$ for both the sticky information model (hereafter, SI) and the lagged inflation indexation model with habits (hereafter, LII) models, so the data do not reject either of the two models. The model-based impulse responses are depicted in figure 2 ,

\footnotetext{
${ }^{12}$ New studies point out to the importance of a varying inflation target as a determinant of inflation persistence (see Cogley, Primeceri, and Sargent, 2009). This approach might have important implications on how we should model inflation dynamics, but this point is left for further research.
} 
where we can see that both model variants do well at replicating the empirical impulse responses embedded by the SVAR. Tables 1 and 2 provide the standard deviation in parenthesis, and the 90 per cent confidence interval for the point estimates. In few cases, though, theses measures are not provided, as the empirical distributions of the estimated parameters, drawn from the bootstrapped method, display a sizable density at either one or two of the extremes of the assumed parameter space. This phenomenon can be a signal of weak identification, as the 90 per cent confidence interval may become uninformative about of the size of the estimating parameter.

Curiously, this phenomenon happens when the point estimate of a parameter is located at one of the extremes, such as the degree of price and wage stickiness in the SI model, the degree of inflation indexation in the LII model, or the output coefficient in the Taylor rule for both models. When it comes to the inflation coefficient in the interest rate rule, the point estimate in both models is higher than its lower bound. However, because the latter is constrained to be equal to 1.001, in order to ensure determinacy, the bootstrapped distribution of the inflation coefficient is also fat tails. In order to extract the most of information from the bootstrapped distribution of these parameters, I compute an interval starting at one of the extremes of the parameter space and ending at its 80 percentile, thus showing the 80 per cent mass of the bootstrapped distribution. If this pseudo-confidence interval is still large or uninformative about the value of a coefficient, than we can suspect that we have a problem of weak identification.

Finally, the horizon for estimation is chosen to be equal to 45 periods. The rationale for a relatively long horizon is that the estimation method is fed with more information about the behavior of the aggregate dynamics. The results for different horizons, available upon request, shows that for small horizons (5 to 20), the estimating parameters are somehow unstable and the models fit is low; while for larger horizons (from 30 to 60 ), the estimating parameters and the model fit do not really vary. Next, the baseline estimation of the LII model is discussed first, followed by the discussion of the SI model.

\subsubsection{Lagged inflation indexation.}

It will prove most convenient to compare the results obtained here with the most popular and accepted versions of this model in the literature. The works of Christiano, Eichenbaum, and Evans (CEE 2005) and Boivin and Giannoni (BG 2006) are particularly useful, as they both use an econometric method that is substantially similar to the one proposed herein. Also, the analysis of Smets and Wouters (SW 2007) is appealing because they use a full-information estimation method that takes into account a broad range of macroeconomic shocks.

Table 1 , row 1 , shows that the habit persistence parameter, $\gamma_{h}^{b}$, is equal to 0.81 , which is some- 
what higher than the value found by $\mathrm{CEE}$ or SW but lower than the estimation of BG. In fact, the estimates of these authors are contained within the 90 per cent confidence interval of $\gamma_{h}^{b}$, which is quite above its lower bound. This result confirms previous results that consumption inertia is an important factor that helps to explain aggregate fluctuations.

The model is characterized by full inflation indexation in both prices and wages, as it can be seen by the point estimates of $\gamma_{p}^{b}$ and $\gamma_{w}^{b}$. This result is also found by BG (2006), and is quite consistent in the bootstrapped estimations, where 80 per cent of the times $\gamma_{p}^{b}$ was estimated between 0.78 and 1 , whereas $\gamma_{w}^{b}$ varied between 0.64 and 1 . The present estimations show that lagged inflation indexation is a very important device for this model to replicate the impulse responses of inflation and output, and is line with the findings of Fuhrer (2006).

When it turns to the degree of nominal rigidities, table 1 shows that $\alpha_{p}^{b}$ and $\alpha_{w}^{b}$ amount to 0.74 and 0.84 , respectively. The model thus predicts that price contracts last on average 3.8 quarters, while for wages the number is 6.2 quarters. BG find a similar prediction for prices (from 4 to 5 quarters), and Fève et al. (2007) with respect to wages (7 quarters). These point estimates are slightly higher than those found by CEE and SW, which amount to 3 quarters for prices, and 3 or 4 quarters for wages. The 90 per cent confidence interval for these parameters confirm that the LII model predicts that both prices and wages are rigid.

One factor that may explain the differences between the CEE and SW results, concerning the degree of nominal rigidities, is that the results from table 1 come from a model that does not assume any role for variable capital utilization, as investment does not enter into the economic dynamics. Interestingly, when CEE remove variable capital utilization or investment adjustment costs from their baseline model, the degree of nominal rigidities substantially increase, and become similar to the point estimates shown here. ${ }^{13}$

We conclude the discussion of the LII model with the policy rule and exogenous shock parameters. The point estimate for the inflation coefficient is 1.41 , and it was estimated between its lower bound of 1 and 2.46 about 80 per cent of the times. Note that one important limitation of this analysis is its apparent inability to draw meaningful insights about the size of $a_{\pi}$, as the estimation period covers at least two different regimes of monetary policy management, namely, the pre- and post-Volcker periods. ${ }^{14}$ In the present analysis, however, I explicitly chose not break

\footnotetext{
${ }^{13}$ Intuitively, by allowing the rate of capital utilization to vary, the volatility of marginal costs is reduced and, everything else equal, so does inflation volatility. As a result, CEE and SW do not need a high degree of nominal rigidities or high indexation to maintain an important degree of inflation inertia (or irresponsiveness); prices are thus allowed to be more flexible.

${ }^{14}$ It has been widely documented that a policy change had effectively taken place in October 1979, when the Fed chairman, Paul Volcker, implemented the policy that presumably led to the period of disinflation and stability of the 1980s.
} 
the sample into sub-samples, given that the SVAR in the period 1980-2007 exhibits a number of pathologies. ${ }^{15}$ Therefore, I follow the strategy of CEE $(1999,2005)$ and adopt a longer sample. Interestingly, however, SW find that $a_{\pi}$ is equal to 1.6 during 1966-1979, and to 1.8 during 19842004. According to their estimations, the Federal Reserve certainly reacted more aggressively to contain inflation in the second sub-sample, but the change was not tremendous. This evidence is also confirmed by Cogley, Primiceri, and Sargent (2009).

Less appealing is the point estimate of the output gap coefficient, which hit the zero bound and that took values between 0 and 0.37 about eighty percent of the time. BG also found that the output gap coefficient is not significant in their baseline results, and SW recognizes that the Federal Reserve do not appears to react strongly to the output gap level.

The size of the monetary policy shock $\left(\sigma_{e}\right)$ matches the impact effect of its SVAR counterpart quite well, as can be appreciated by figure 2 . Further, the shock is quite persistent $\left(\rho_{e}=0.92\right)$, which implies that the interest rate would reflect an important degree of smoothing. ${ }^{16}$

To recap, the LII model presented here requires inflation indexation in order to match the dynamics of the monetary SVAR. It also predicts that price and wage contracts last 4 and 6 quarters on average, respectively. Finally, the estimations shown herein do not differ substantially from previous studies in the literature, either those estimated through minimum distance estimation (like CEE or BG), or those that consider full-information methods (like SW).

\subsubsection{Sticky information}

The point estimates are presented in table 2 , row 1 . When it turns to the degree of information stickiness, the results of table 2 suggest that households $\left(\gamma_{h}^{s i}\right)$ update information every 10 quarters on average (i.e. $1 /[1-.90]$ ). Notice that the lower bound of the 90 per cent confidence interval of $\gamma_{h}^{s i}$ lies well above zero, which implies that the assumption that households update information only infrequently is not ruled out by the data. The value of $\gamma_{p}^{s i}$ suggests that firms update information every 3 quarters on average, whereas for workers $\left(\gamma_{w}^{s i}\right)$ the number is 4.8 quarters. The 90 percent confidence interval for these measures range from 2 to 4.5 quarters

\footnotetext{
${ }^{15}$ For example, output persistently rises after a contractionary shock in monetary policy. In addition, the estimated IRFs are not precisely estimated, implying that estimating DSGE parameters in order to replicate these responses is meaningless. This phenomenon is reminiscent of the point raised by Sims (1998) that SVARs estimated on a short time series can produce very erratic IRFs. In addition, Sims and Zha (2006) have found more evidence for stable dynamics with unstable disturbance variances than for clear changes in model dynamics. See also Leeper and Roush (2003) and Rudebusch and Wu (2004).

${ }^{16}$ Notice that an explicit term for policy inertia was excluded from the Taylor rule in equation (5). The latter follows recent studies that point out a predominant role for persistent monetary shocks, rather than a high degree of policy inertia, in explaining the dynamics of certain U.S. macro variables (see Rudebusch, 2006; or Carrillo et al., 2007).
} 
for firms, and from 2.5 to 6.2 quarters for workers. Let us compare these results with those of previous studies.

The number of papers that aim to estimate different versions of the SI model lately substantially increased. Table 4 presents a selective review of these works. Although the variety of quantitative methods is rich, which offers several perspectives from where the results of table 2 can be compared, only a few works have a general equilibrium approach, and even fewer consider the case of pervasive stickiness. Among the latter, only Mankiw and Reis (MR 2006 and 2007) and Reis (2009) estimate the values of $\gamma_{h}^{s i}, \gamma_{p}^{s i}$, and $\gamma_{w}^{s i}$ using a general-equilibrium framework. In addition, at least to my knowledge, the results presented in table 2 are for the first time delivered by a method that directly focuses on the aggregate effects of a shock to monetary policy.

The vast majority of papers cited on table 4 assume sticky information only on price decisions. As such, we can see that the firms' estimated elapsed time for information updating ranges from 1.4 to 6.7 quarters. The point estimate of $\gamma_{p}^{s i}$ and its confidence interval lie well within this range. Further, the point estimate of $\gamma_{w}^{s i}$ in table 2 is very close to the one found by MR (2007), in which they perform a Bayesian estimation over a very similar sample period. Finally, the point estimate of $\gamma_{h}^{s i}$ is similar to the results of Reis (2009), who uses Bayesian estimation over the post-1986 data. Notice that there seems to be a regularity in the estimations that consider pervasive stickiness: firms and workers tend to be more attentive than households.

The sticky information model depicted in Section 2.3 is specially designed to answer the question of whether pervasive sticky information can replace entirely sticky prices and wages. Remember that this model variant allows for dual stickiness, thus enabling both kinds of rigidities to interact with one another in a general-equilibrium framework. The results presented in table 2 suggest that sticky information is the relevant friction concerning at least price-setting behavior. Both point estimates of $\alpha_{p}^{s i}$ and $\alpha_{w}^{s i}$ equal zero. Further, $\alpha_{p}^{s i}$ was located between 0 and 0.32 about eighty percent of the time, according to the bootstrapped estimations. The SI model thus interprets that prices are more flexible than the LII model does. For wages, the result is less robust. Following table 2, the distribution of $\alpha_{w}^{s i}$ has 80 percent of its mass between the support values of 0 and 0.75 . Even though the latter do not contains the point estimate $\alpha_{w}^{b}$ according to the LII model, the large scope of the interval does not allow one to conclude that wages are fully flexible according the SI model.

Recent studies, such as Knotek (2006), Dupor et al. (2009), or Coibion and Gorodnichenko (2009) have also asked if sticky information can replace entirely sticky prices. They do not study the influence of sticky information over wage rigidities, as they assume that workers are fully attentive. The results of these authors suggested that a model containing both sticky prices 
and sticky information better fits the data than assuming sticky information in isolation. Their estimation of $\alpha_{p}^{s i}$ is greater than zero and significant. This result contrasts the findings of table 2. One factor that may explain these conflicting conclusions is the framework in which the same question was asked. Dupor et al. (2009) and Knotek (2006) both use partial equilibrium analysis. Therefore, their estimations might miss important information coming from the crossequations restriction of a full-fledged DSGE model. To verify this hypothesis, table 2, row 8 , display the estimation results of the SI model when only firms are subject to sticky information (thus $\gamma_{h}^{s i}=\gamma_{w}^{s i}=0$, by assumption). Although the point estimate of $\gamma_{h}^{s i}$ is quite similar to the baseline, and the estimate of $\alpha_{p}^{s i}$ is greater than zero, this variant of the SI model is rejected by the data at the 5 per cent significance level. The p-value of the associated $\mathcal{J}_{T}$ statistic is equal to 0.02 . Therefore, cross-equation restrictions are important. The robustness analysis discusses the dimensions in which this variant of the SI model fails.

Coibion and Gorodnichenko (2009) use a complete DSGE model, in which sticky-price firms cohabit with sticky-information firms. The discrepancy in our conclusions might perhaps be explained by the following. The authors do not consider any wages rigidities, which may represent a determinant factor to explain macroeconomic persistence, as pointed out by Christiano et al. (2005). The robustness analysis summarizes the case of the SI model with attentive workers, where it is shown that the fit of the model is inferior to the baseline case. ${ }^{17}$

Finally, the parameters concerning the policy rule according to the SI model are examined. Here, replacing lagged inflation indexation with pervasive information stickiness does not significantly alter the size of the policy rule parameters or the properties of the monetary policy shock. Accordingly, the nominal interest rate will show a sizable degree of smoothing due to high persistent shocks. It also reacts in a more then a one-to-one basis to changes in inflation and does not appear to be affected by the output gap. Interestingly, Reis (2009), when estimating a pure version of the SI model, found similar results concerning the output gap coefficient.

\subsubsection{Goodness of fit}

In order to evaluate the degree of accuracy of the LII and SI models, I compute the root-meansquared error (RMSE) between the model-based IRFs and the SVAR IRFs. The RMSE is

\footnotetext{
${ }^{17}$ Another reason is that our estimation methodologies are different. The aim of the authors is to match the serial- and cross-correlations of aggregate variables, and they do so using MDE, while in the present analysis, the moments to match are the responses of aggregate variables to a monetary policy shock. The accuracy of each approach can be assessed by asking how well both approaches approximate the behavior of output and inflation after a shock in monetary policy. The responses obtained by Coibion and Gorodnichenko (2009) fail to reproduce the characteristic hump-shaped profile of inflation and output.
} 
calculated for each of the variables consider for estimation, thus

$$
R M S E(x)=\frac{1}{K} \sum_{t=1}^{K}\left(h_{t}\left(\psi_{2} ; x\right)-\hat{\theta}_{t}(x)\right)^{2},
$$

where $h_{t}\left(\psi_{2} ; x\right)$ and $\hat{\theta}_{t}(x)$ are the model-based IRF and SVAR IRF for variable $x$, respectively; $K$ is the estimating horizon $(=45)$; and $x \in\left\{y, \pi, \pi^{w}, i\right\}$ refers to output, inflation, wage inflation, and the interest rate. That is, the $\operatorname{RMSE}(x)$ is a measure of the distance between the dynamics predicted by each of the models and the those that are embedded by the SVAR with respect to variable $x$. We can use the bootstrapped samples employed in the estimation of the LII and SI baseline models in order to infer the associated distribution of the $R M S E(x)$ statistic. This method will give us an idea of how different the models are in terms of their ability to fit the aggregate dynamics of the SVAR. Figure 3 displays the bootstrapped distribution of the $R M S E(x)$ for each model, according to the baseline estimations of tables 1 and 2 . As can be seen, the distribution of $R M S E\left(\pi^{w}\right)$ and $R M S E(i)$ do not really differ from model to model. This result indicates that the two models are equally good in explaining wage inflation and the federal funds rate dynamics. When it comes to output, the mean and mode of $R M S E(y)$ according to the LII model slightly lean to the right with respect to the SI model. This finding indicates that, on average, the LII model fits slightly better to output dynamics. Finally, concerning inflation, the opposite is true. The SI model appears to predict the dynamics of inflation slightly better than the LII model does. Further analysis is provided in the robustness analysis.

\section{Robustness analysis}

This section re-estimates the LII and SI models for different calibration of certain parameters concerning preferences and technology. Additionally, an alternative measure of the output gap is considered, which corresponds to the percentage difference between actual output and the Congressional Budget Office (CBO) forecast of potential output, that is, the CBO output gap. I also consider an alternative ordering in the monetary SVAR. It is assumed that consumers, workers, and firms make their decisions after the central bank decides the level of the interest rate. That is, the ordering of matrix $Z_{t}$ in Section 3 changes to $Z_{t}=\left(\hat{\imath}_{t}, Z_{1, t}^{\prime}, Z_{2, t}^{\prime}\right)^{\prime}$, or the interest rate moves first. Although the hump-shaped patterns of inflation, wage inflation, and output are preserved, this identification strategy shows a couple of pathologies. For instance, output and wage inflation increase on impact after a contractionary shock to monetary policy, while inflation shows a significant price puzzle in quarters 2 to 4 . The latter is difficult to justify with a theoretical model. However, it is on these adverse circumstances that we might test the parameter stability of the estimation method concerning the hump-shaped behavior of aggregate 
variables.

For the SI model, I additionally consider different assumptions about information frictions. First, it is assumed that firms are subject to sticky information, while consumers and workers are fully attentive. Then, it is assumed that consumers and firms are inattentive, while workers are fully attentive. And finally, it is assumed that only firms possess full information. The latter has the intention to verify whether pervasive sticky information is a necessary feature to fit inflation and output inertia.

Changes in calibration. The results are as follows. Reducing the Frisch elasticity of labor supply, $\omega_{w}^{-1}$ from 1 to .1 , slightly reduces the degree of wage rigidities in the LII model and increases the workers' rate of updating information in the SI model. The latter can be explained by an increase in the degree of strategic complementarities between wage setters (which is reflected by a decrease in the parameter $\xi_{w}$ in eq. 10 and 16) which results from a reduction in the volatility of working hours. While the reduction of the degree of wage rigidities is the only remarkable change in the LII model, the point estimate of the degree of price rigidities rises to .44 in the SI model. This is nevertheless substantially lower than the same estimating parameter of the LII model. Additionally, 80 percent of the mass for this parameter estimate is located between zero and .47. In addition, the bootstrapped distribution of $\alpha_{p}^{s i}$ predicts that the probability that $\alpha_{p}^{s i}$ is smaller or equal than $\alpha_{p}^{b}$, conditional to the calibration where $\omega_{w}^{-1}=.1$, is equal to 93 per cent. The latter means that the SI model predicts that prices are more flexible than the LII model with more than 10 per cent of significance, when it is assumed that the labor supply is very inelastic. Note that changes in the parameter $\theta_{w}$ have similar effects to changes in $\omega_{w}^{-1}$, as both parameters affect the degree of strategic complementarities between wage setters similarly.

Reducing the level of risk aversion, $\sigma$, from 1 to .5 , increases the level of habit persistence in the LII model and decreases the consumers' rate of updating information in the SI model. Because consumers are less risk averse, they are more willing to change consumption today for consumption in the future. As a consequence, the parameters that create inertia in output are estimated to be higher. However, the rest of the parameters remain very similar to the baseline calibration. Finally, assuming values of $\sigma$ lower than 1 is not common in the literature. For instance, Christiano et al. (2005) and Mankiw and Reis (2007) set $\sigma$ equal to 1, whereas Smets and Wouters (2007) find that $\sigma$ is 1.4 .

Switching off the Kimball aggregator in the final good producers' technology, or assuming that 
the latter have a Dixit-Stiglitz aggregator and thus that $\epsilon_{\mu}=0$ increases price rigidities in the LII model, while reduces the firms' rate of updating information in the SI model. A similar result is found in Eichenbaum and Fisher (2004), who find that the frequency of price adjustments increases when the Kimball technology is assumed. The latter is explained by an increase in the degree of strategic complementarities between price setters (see definition of $\xi_{p}$ in eq. 9 and 15). The results of the LII and the SI models are in line with this finding. Once again, changes in the parameters $\theta_{p}(1)$ or $s_{q}$ have similar effects as changes in $\epsilon_{\mu}$, as they affect in a similar way the degree of strategic complementarities between price setters.

Assuming a linear technology in terms of labor in the intermediate sector, that is, $\phi=1$, reduces the degree of price rigidities in the LII model and increases the firms' rate of updating information in the SI model. The reason for this changes is that the marginal cost of intermediate firms becomes less volatile. To see this decreases in volatility, consider that the function $F\left(n_{t}\right)$ in eq. 3 is a Cobb-Douglas. The log-linearized version of the latter thus implies that in equilibrium $\hat{y}_{t}=\phi^{-1} \hat{n}_{t}$ and $\omega_{p}=\phi-1$. The baseline calibration assumes decreasing returns to scale on labor, that is, $\phi^{-1}>1$. The latter implies that if output changes by one percent, labor changes by more than one per cent, which is weighted in the marginal costs in eq. 9 and 15 by the parameter $\omega_{p}$. By assuming a linear technology, labor changes as much as output, making the marginal costs less volatile, as reflected by the value of $\omega_{p}=0$. As a result, a linear technology does not require much rigidity in prices. Assuming, though, that the labor income's share of output is equal to 1 is not very realistic. In any case, other parameters in the model are not significantly affected.

In sum, considering alternative calibrations does not modify the main conclusions of the baseline estimation.

Alternative SVAR specifications. Changing the measure of output to the CBO output gap or assuming an alternative ordering in the SVAR does not alter the main conclusions reached with the baseline estimations. Tables 1 and 2, rows 6 and 7, show the estimating parameters with the alternative SVAR specifications. As can be observed, the consumption inertia parameters are somewhat increased, whereas the effect for prices and wages is mixed. Nonetheless, the qualitative findings of the baseline estimation are not modified. The reason behind this result relies on the aggregate inertia that the alternative SVAR specifications present. Hump-shaped behavior over a sizable horizon is conserved in those specifications, which allows the estimation method to choose similar parameters values than in the baseline case. 
Goodness of fit. Concerning the goodness of fit of each model, table 3 displays the mode and the 90 per cent confidence interval around the median of the $R M S E(x)$ statistic, where $x \in\left\{y, \pi, \pi_{w}, i\right\}$ stands for output, inflation, wage inflation, and the fed funds. The original values are multiplied by 1000 , for better readability. The table shows two regularities that can be clearly observed: first, the LII model systematically achieves a lower $R M S E$ mode in terms of output; and second, the SI model reaches a lower RMSE mode for inflation. On average, the mode of $R M S E(y)$ according to the SI model is 25 per cent higher than the same statistic for the LII model. Similarly, the mode of $R M S E(\pi)$ according to the SI model is 12 per cent lower than the same statistic for the LII model. For the fed funds and wage inflation, the difference is just about 5 per cent. Therefore, the SI model has a modest advantage in explaining inflation behavior, while the LII model has it for output. Figure 3 shows the bootstrapped distributions of the RMSE statistics for the baseline model. The picture shows that the distribution for $R M S E(y)$ and $R M S E(\pi)$ differ from model to model. The latter is true as well for all the estimations considered in the robustness analysis.

To answer the question of whether these differences are significant, we can verify whether the 90 per cent confidence interval around the median of $R M S E(x)$ according to one model contains the mode of $R M S E(x)$ according to the other model. With respect to output, table 3 shows that, in general, the mode of $R M S E(y)$ according to the LII model is contained in the 90 per cent confidence interval of the SI model, except for rows 3 and 4 . With respect to inflation, the mode of $R M S E(\pi)$ according to the SI model is in all cases inside of the 90 per cent confidence interval of the LII model. Therefore, even though the differences in the modes of the RMSE statistic for inflation and output are consistent across the robustness analysis, they are in general not statically significant.

Different information structure for the Sticky information model. This section concludes with the analysis of different assumptions about the type of agents who confront information frictions. The vast majority of studies that estimate the sticky information model assume that only firms are subject to a slow diffusion of information. Table 4 shows few of these studies, and their findings. This assumption is equivalent to constrain the values of $\gamma_{h}^{s i}$ and $\gamma_{w}^{s i}$ equal to zero. The estimation of the SI model with only inattentive firms is shown in row 8 of table 2 . As we can see by the $\mathcal{J}_{T}$ statistic, the data rejects at a 5 per cent significance the assumption that only firms suffer information frictions. In terms of the goodness of fit, the constrained SI model has a poorer performance for all variables, as shown by row 8 in table 3 . In the same vein, assuming that consumers and workers face information frictions, while firms have full information (thus, $\gamma_{p}^{s i}=0$ ) is rejected by the data at a 10 per cent of significance (table 2 , last row). 
Finally, assuming that firms and consumers are inattentive, while workers are fully informed (thus, $\gamma_{w}^{s i}=0$ ), is barely tolerated by the data (the p-value of the $\mathcal{J}_{T^{-}}$-stat in table 2 , row 9 , is equal to .11). This alternative assumption makes the SI model more inaccurate with respect to the baseline in all variables, as shown by table 3 , row 9 . Thus, in order to match the behavior of output, inflation, wage inflation, and the fed funds, the SI model requires that all agents in the economy be subject to information frictions.

\section{Discussion}

Given the evidence provided in the last section, it is hard to choose between the LII model and the SI model as the environment that represents a closer description of reality. This difficulty is do to the fact that the dynamics after a shock in monetary policy are not significantly different between models. As a result, one may ask whether there are other dimensions that can give us arguments to differentiate between models.

\subsection{Microeconomic evidence about the frequency of price changes}

One of these dimensions might be given by microdata studies that aim to characterize the frequency of price changes. The evidence for U.S. is the following. Bils and Klenow (2004) and Klenow and Kryvtsov (2008) show that 50 per cent of prices change in 4 months or less. On the other hand, this result depends on whether sale prices are taken into account, as Nakamura and Steinsson (2008) point out. Removing sales increases the median duration between price changes to 7 or 9 months. On the other hand, the real question is whether sales should actually be excluded from this kind of studies, and the answer is not obvious. Sales should be filtered out if they behave as orthogonal movements to macroeconomic variables. We might ask then, do sales react differently than regular prices to macroeconomic innovations? An answer is provided by Klenow and Willis (2007), who find that sale price changes are at least as sensitive to inflation as regular price changes are. As a result, sales may not be filtered out of the analysis or, at least, we should try to understand exactly what kind of information sales have.

Now assume that each of the model price reoptimizations can be interpreted as price readjustments or changes. Further, neglect for the moment any aggregation issues that might stop us from comparing microdata evidence about the frequency of price changes with the macroeconomic perception of price readjustments. If we would like to link the prediction of price changes according to one of the models, we would have to conclude that the LII model is in accordance to the evidence of Nakamura and Steinsson (2008), while the SI model is in line with the evidence of Bils and Klenow (2004) and Klenow and Willis (2007). The reason is that the LII model predicts that prices are reoptimized on average once per year, whereas the SI model predicts 
that prices are reoptimized every quarter, but firms react to old information. Evidently, the models described in Section 2 do not distinguish between regular and sale prices, and yet it appears that the information contained in sales might help in choosing one of the two models as more accurate representation of macroeconomic dynamics.

\subsection{Different shocks and the real wage}

Another dimension which may assess the differences between the LII and the SI models, is to investigate how each model reacts to other shocks that do not refer to monetary policy. For instance, we can consider a neutral-technology shock and a government-spending shock. For the former, we can assume that every intermediate-good producer is subject to a common productivity disturbance. In addition, we can assume that, in the steady state, the ratio of government purchases to GDP is equal to 19 per cent in the resource constraint. The latter equals the historical ratio in the U.S. for the last 10 years. Further, we can assume that both shocks follow AR(1) processes, with persistence values calibrated as in Smets and Wouters (2007) (thus, $\rho_{a}=.95$ and $\rho_{g}=.97$ for technology and government purchases, resp.). Figures 4 and 5 show the models' responses to a positive shock in technology and a 1 per cent increase of GDP in government purchases.

In terms of the technology shock, the SI model predicts a smaller boom in output and consumption than the LII model, while the dynamics of inflation are very similar. Also noticeable, is that the peak effect in wage inflation is reached several quarters later in the SI model than in the LII model. The most remarkable difference, though, relies on the responses of the real wage. Even though the latter reacts less strongly than output in both models (in terms of percentage deviations from the steady state), the SI model predicts a higher volatility in the real wage than the LII model. Now let us see if this prediction is also true for a demand-side shock.

When government purchases increase by 1 percent of GDP, the SI model predicts that consumption is not crowded out as much as in the LII model. This prediction implies that the responses of output are slightly more pronounced under the SI model. Once again, inflation somehow has similar dynamics in both models, and again, the peak effect of wage inflation under the SI model happens a few quarters after the one predicted by the LII model. Finally, it the real wage is again smoother under the LII model than under the SI model.

It thus appears that the dynamics of the real wage may contain further information that will help to choose one of the two models as a better description of aggregate dynamics. Lately, Liu and Phaneuf (2007) and Riggi and Tancioni (2010) investigated the effects of technology shocks on real wages. Their inquiries may help to close the race between the two models described in 
this paper. However, this point is left for further research.

\section{Concluding remarks}

The present study considers two alternative devices that aim to explain the persistent behavior of output and inflation that have been documented after a shock in monetary policy. A baseline model, that considers price and wage rigidities à la Calvo plus other real rigidities, is added with two specifications that create intrinsic persistence to macro variables. The first one adds habit formation to consumption decisions, plus a lagged inflation indexation rule for firms and workers that are unable to reoptimize their prices and wages in a certain period. The second specification adds sticky information to households, firms, and workers, thus assuming that there is a pervasive slow diffusion of information that applies to all the population. Both models are then compared to the estimated aggregate responses to a monetary policy shock resulting from a monetary SVAR for the U.S., using the sample period 1960(1)-2007(2).

The analysis finds that, in general, the lagged inflation indexation model has a modest advantage for predicting output, whereas for inflation is the pervasive sticky information model that has a slightly better performance. These differences, however systematic on the robustness analysis, are not sufficiently great to imply any statistical significance in terms of the goodness of fit of each model, measured by the root mean squared error. Further, the estimated version of the sticky information model suggest that inattentive firms may replace entirely sticky prices as an explanation of price-setting behavior. For wages, the conclusion is less robust. Finally, the results also suggests that the best environment to study sticky information models is one in which all type of agents face information frictions. Assuming that only firms are inattentive is rejected by the data. In addition, assuming that either firms or worker are attentive and thus that information stickiness is not pervasive, results in a poor goodness of fit of the sticky information model.

In terms of the evidence reported herein, is difficult to decide whether a researcher should pick one of the two models in order to study inflation and output inertia. Trying to link the predictions of the two models with microeconomic evidence about the frequency of price changes does not help much either. The reason is that the lagged inflation indexation model is in line with the evidence of Nakamura and Steinsson (2008), which points out that prices change once per year. This result is due the fact that these authors do not include sale prices in their sample. On the other hand, the pervasive sticky information model is in line with the evidence of Bils and Klenow (2004) and Klenow and Willis (2007), which suggest that prices change every quarter but react to old information. These results are due to these authors including sale prices in their 
analysis. Whether sale prices should be included is a subject of controversy in the field, since Klenow and Willis (2007) report that sale prices react as much as regular prices to changes in inflation.

Finally, Section 6.2 reviews the responses of each model to other non-monetary shocks. The main difference relies on the dynamics of the real wage, where the pervasive sticky information model predicts a more volatile response than the lagged inflation indexation model. Therefore, real wages might contain some information that could help us to discriminate between the two models. This hypothesis is left for future research.

\section{References}

[1] Andrés, J., López-Salido, J.D., and Nelson, E., 2005. Sticky Price Models and the Natural Rate of Hypothesis. Journal of Monetary Economics, 52, 1025-1053.

[2] Altig, D., Christiano, L.J., Eichenbaum, M., Linde, J., 2005. Firm-specific capital, nominal rigidities, and the business cycle. NBER working paper 11034.

[3] Amato, J.D., Laubach, T., 2003. Estimation and control of an optimization-based model with sticky prices and wages. Journal of Economic Dynamics and Control, 27, 1181-1215.

[4] Bils, M., Klenow, P.J., 2004. Some evidence on the importance of sticky prices. Journal of Political Economy, 112, 947-985.

[5] Boivin, J., Giannoni, M.P., 2006. Has monetary policy become more effective? Review of Economics and Statistics, 88, 430-450.

[6] Bruchez, P.A., 2007. A hybrid sticky-price and sticky information model. Manuscript.

[7] Canova, F. and Sala, L., 2009. Back to square one: identification issues in DSGE models. Journal of Monetary Economics, 56, 431-49.

[8] Carrillo, J. A., Matheron, J., Fève, P., 2007. Monetary policy inertia or persistent shocks: A DSGE Analysis. International Journal of Central Banking, 3, 1-38.

[9] Carroll, C. D., 2003. Macroeconomic Expectations of Households and Professional Forecasters. Quarterly Journal of Economics, 118, 269-298.

[10] Chari, V.V., Kehoe, P.J., McGrattan, E.R., 2000. Sticky price models of the business cycle: Can the contract multiplier solve the persistence problem? Econometrica, 68, 1151-79.

[11] Christiano, L.J., Eichenbaum, M., Evans, C.L., 1996. The effects of monetary policy shocks: Evidence form the flow of funds. Review of Economics and Statistics, 78, 16-34. 
[12] Christiano, L.J., Eichenbaum, M., Evans, C.L., 1999. Monetary policy shocks: What have we learned and to what end? In: Taylor, J.B., Woodford, M. (Eds.), Handbook of Macroeconomics, Vol. 1A. Elsevier, Amsterdam, 65-148.

[13] Christiano, L.J., Eichenbaum, M., Evans, C.L., 2005. Nominal rigidities and the dynamic effects of a shock to monetary policy. Journal of Political Economy, 113, 1-45.

[14] Cogley, T., Primiceri, G.E., Sargent, T.J., 2009. Inflation-ga persistence in the U.S. Mimeo.

[15] Coibion, O., 2010. Testing the sticky information Phillips curve. Review of Economics and Statistics, 92, 87-101.

[16] Coibion, O., Gorodnichenko, Y., 2009. Strategic interaction among heterogeneous pricesetters in an estimated DSGE model. National Bureau of Economic Research, NBER Working Papers 14323.

[17] Dupor, B., Kitamura, T., Tsuruga, T., 2009. Integrating sticky prices and sticky information. Review of Economics and Statistics, forthcoming.

[18] Eichenbaum, M., 1992. Comment on "Interpreting the macroeconomic time series facts: the effects of monetary policy". European Economic Review, 36, 1001-1011.

[19] Eichenbaum, M., Fisher, J.D.M., 2004. Evaluating the Calvo model of sticky prices. National Bureau of Economic Research, NBER Working Papers 10617.

[20] Erceg, C.J., Henderson, D.W., Levin, A.T., 2000. Optimal monetary policy with staggered wage and price contracts. Journal of Monetary Economics, 46, 281-313.

[21] Fuhrer, J., 2006. Intrinsic and inherited inflation persistence. International Journal of Central Banking, 2, 49-86.

[22] Fuhrer, J., Moore, G., 1995. Inflation Persistence. Quarterly Journal of Economics, 110, $127-160$.

[23] Galí , J., Gertler, M., 1999. Inflation Dynamics: A Structural Econometric Analysis. Journal of Monetary Economics, 44, 195-222.

[24] Giannoni, M.P., Woodford, M., 2004. Optimal inflation targeting rules. In: Bernanke, B.S. and Woodford, M., (Eds.), The Inflation Targeting Debate. University of Chicago Press, Chicago, 93-162.

[25] Kahn, H., Zhu, Z., 2006. Estimates of the sticky information Phillips Curve for the United States. Journal of Money, Credit and Banking, 38, 195-208. 
[26] Kiley, M., 2007. Quantitative Comparison of Sticky-Price and sticky information Models of Price Setting. Journal of Money, Credit and Banking, 39, 101-125.

[27] Kimball, M.S., 1995. The quantitative analytics of the basic neomonetarist model. Journal of Money, Credit and Banking, 27, 1241-1277.

[28] Knotek, E.S.II., 2006. A tale of two rigidities: sticky prices in a sticky-information environment. Federal Reserve Bank of Kansas City, Research Working Paper RWP 06-15.

[29] Klenow, P. and J. Willis., 2007. Sticky Information and Sticky Prices. Journal of Monetary Economics, 54, 79-99.

[30] Korenok, O., 2008. Empirical comparison of sticky price and sticky information models. Journal of Macroeconomics, 30, 906-927

[31] Korenok, O., Swanson, N.R., 2007. How sticky is sticky enough? A distributional and impulse response analysis of New Keynesian DSGE models. Journal of Money, Credit and Banking, 39, 1481-1508.

[32] Lieb, L., 2009. Taking real rigidities seriously: Implications for optimal policy design in a currency union. Research Memoranda 032, Maastricht, Maastricht Research School of Economics of Technology and Organization.

[33] Liu, Z., Phaneuf, L., 2007. Technology shocks and labor market dynamics: Some evidence and Theory. Journal of Monetary Economics, 54, 2534-2553.

[34] Mankiw, G., Reis, R., 2002. Sticky Information versus Sticky Prices: a Proposal to Replace the New Keynesian Phillips Curve. Quarterly Journal of Economics, 117, 1295-1328.

[35] Mankiw, G., Reis, R., 2006. Pervasive Stickiness. American Economic Review, 96, 164-169.

[36] Mankiw, G., Reis, R., 2007. Sticky Information in General Equilibrium. Journal of the European Economic Association, 5, 603-613.

[37] Meyer-Gohde, A. 2010. Linear Rational Expectations Models with Lagged Expectations: A Synthetic Method. Journal of Economic Dynamics and Control, forthcoming.

[38] Mojon, B., Peersman, G., 2003. A VAR description of the effects of monetary policy in the individual countries of the Euro Area. In: Angeloni, I., Kashyat, A., Mojon, B. (Eds.), Monetary policy transmission in the Euro Area, Cambridge University Press, Cambridge.

[39] Nakamura, E., Steinsson, J., 2008. Five facts about prices: A reevaluation of menu cost models. The Quarterly Journal of Economics, 123, 1415-64. 
[40] Reis, R., 2009. Optimal Monetary Policy Rules in an Estimated Sticky-Information Model. American Economic Journal: Macroeconomics, 1, 1-28.

[41] Riggi, M., Tancioni, M., 2010. Nominal v. real wage rigidities in new keynesian models with hiring costs: A bayesian evaluation. Journal of Economic Dynamics and Control, forthcoming.

[42] Rotemberg, J.J., Woodford, M., 1995. Dynamic general equilibrium models with imperfectly competitive product markets. In: Cooley, T. F. (Ed.), Frontiers of Business Cycle Research, chapter 9, pages 243-293. Princeton University Press, Princeton.

[43] Rotemberg, J.J., Woodford, M., 1997. An optimization-based econometric framework for the evaluation of monetary policy. In: Bernanke, B.S., Rotemberg, J.J. (Eds.), NBER Macroeconomics Annual. MIT Press, Cambridge, 297-346.

[44] Rotemberg, J.J., Woodford, M., 1999. Interest-rate rules in an estimated sticky price model. In: Taylor, J.B. (Ed.), Monetary Policy Rules. University of Chicago Press, Chicago, 57-119.

[45] Rudebusch, G.D., 2006. Monetary policy inertia: Fact or fiction? International Journal of Central Banking, 2, 85-135.

[46] Rudebusch, G.D., Wu, T., 2008. A macro-finance model of the term structure, monetary policy and the economy. Economic Journal, 118, 906-26.

[47] Runkle, D.E., 1987. Vector autoregressions and reality. Journal of Business and Economic Statistics, 5, 437-42.

[48] Sims, C.A., 1992. Interpreting the macroeconomic time series facts: the effects of monetary policy. European Economic Review, 36, 975-1000.

[49] Smets, F., Wouters, R., 2007. Shocks and frictions in U.S. business cycles: A Bayesian DSGE approach. American Economic Review, 97, 586-606.

[50] Sousa, J., Zaghini, A., 2008. Monetary policy shocks in the Euro Area and global liquidity spillovers. International Journal of Finance and Economics, 13, 205-18.

[51] Taylor, J.B., 1993. Discretion versus policy rules in practice. Carnegie-Rochester Conference Series on Public Policy, 39, 195-214.

[52] Trabandt, M., 2007. Sticky Information vs. Sticky Prices: A Horse Race In A DSGE Framework. Sveriges Riksbank Working Paper Series 209.

[53] Wang, P., Wen, Y., 2007. Inflation dynamics: A cross-country investigation. Journal of Monetary Economics, 54, 2004-31. 
[54] Woodford, M., 2003. Interest and Prices: Foundation of a Theory of Monetary Policy. Princeton University Press, Princeton. 
Figure 1: The monetary SVAR, shock to monetary policy
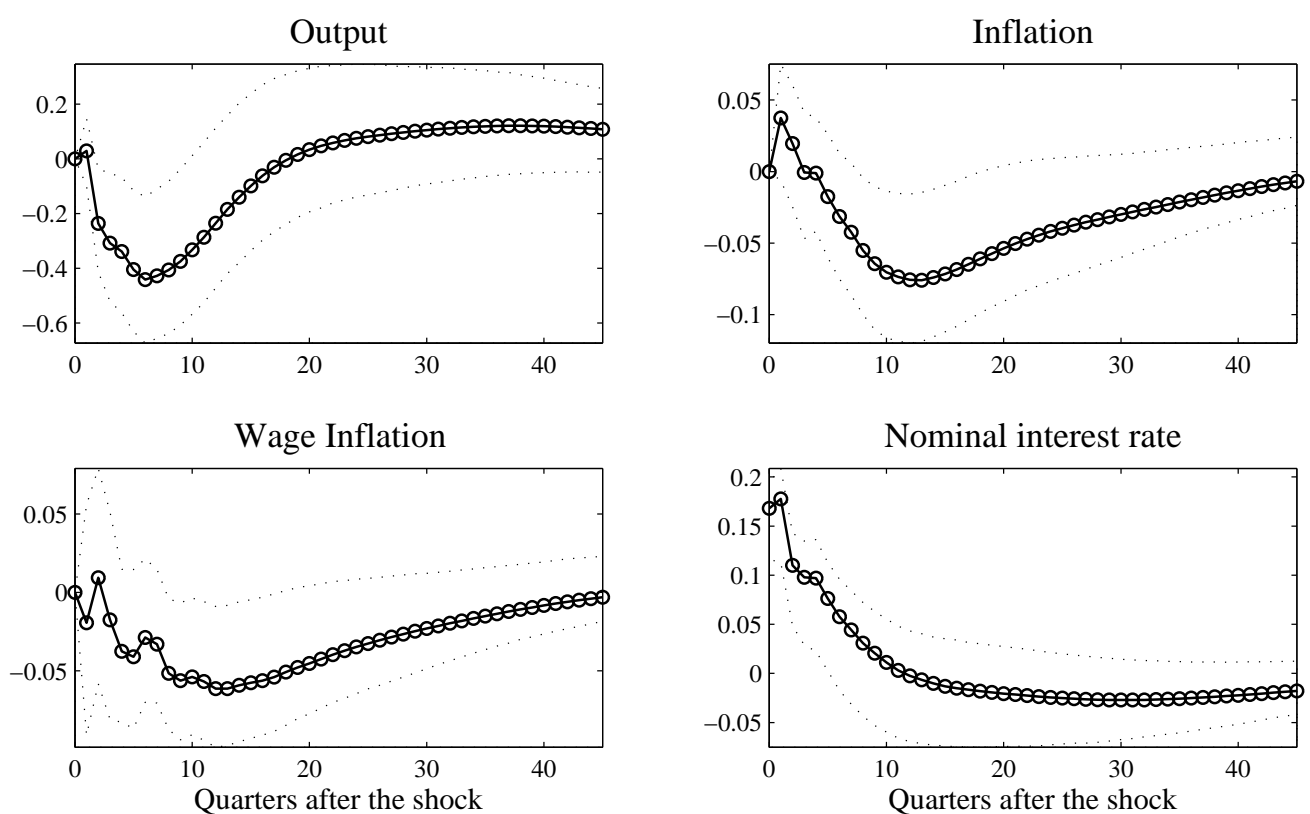
Figure 2: Fit of sticky information and lagged inflation indexation
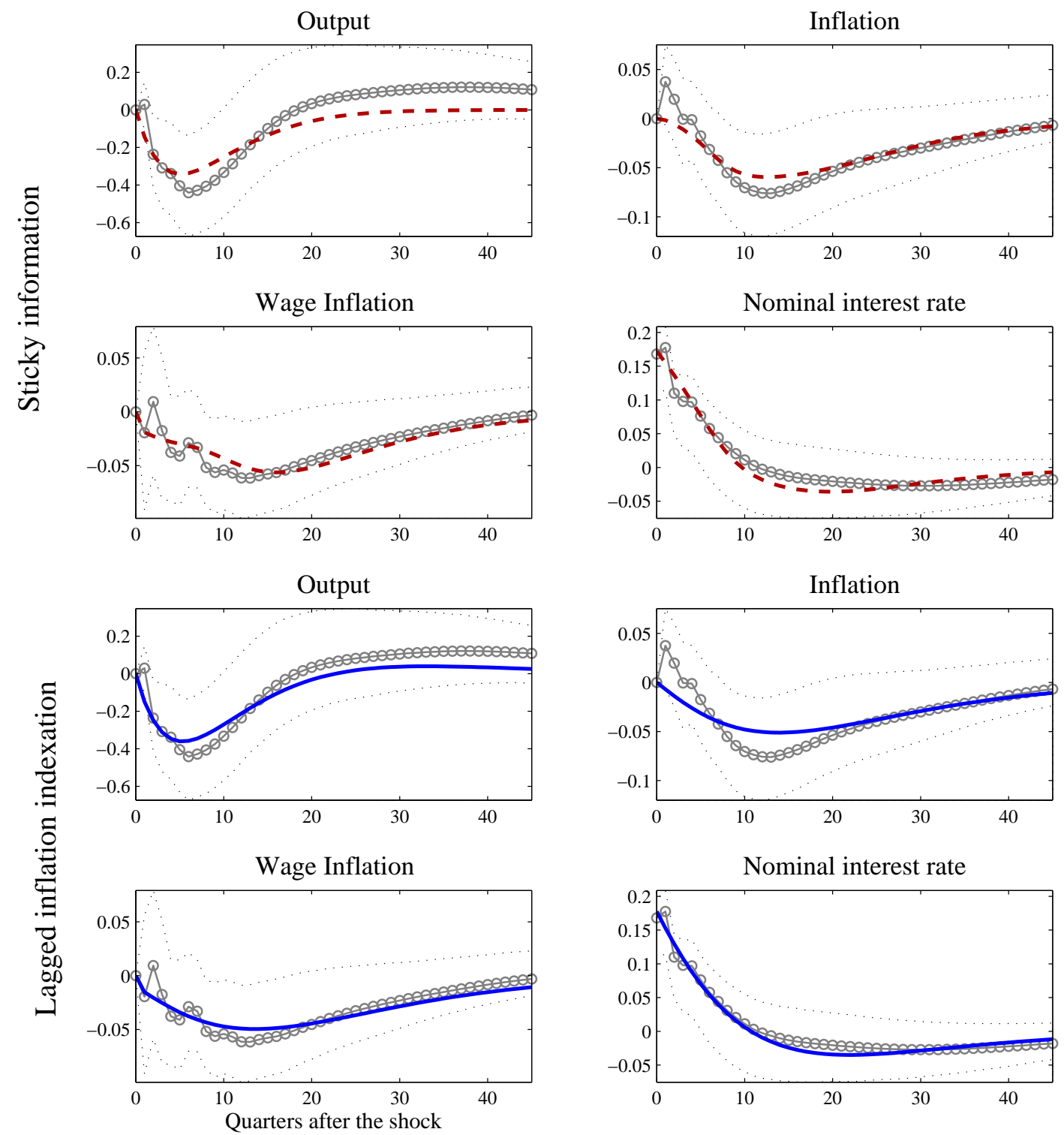

- $\mathrm{SVAR}$ - - - Sticky information

L Lagged inflation indexation 
Figure 3: RMSE for the bootstrapped baseline estimation
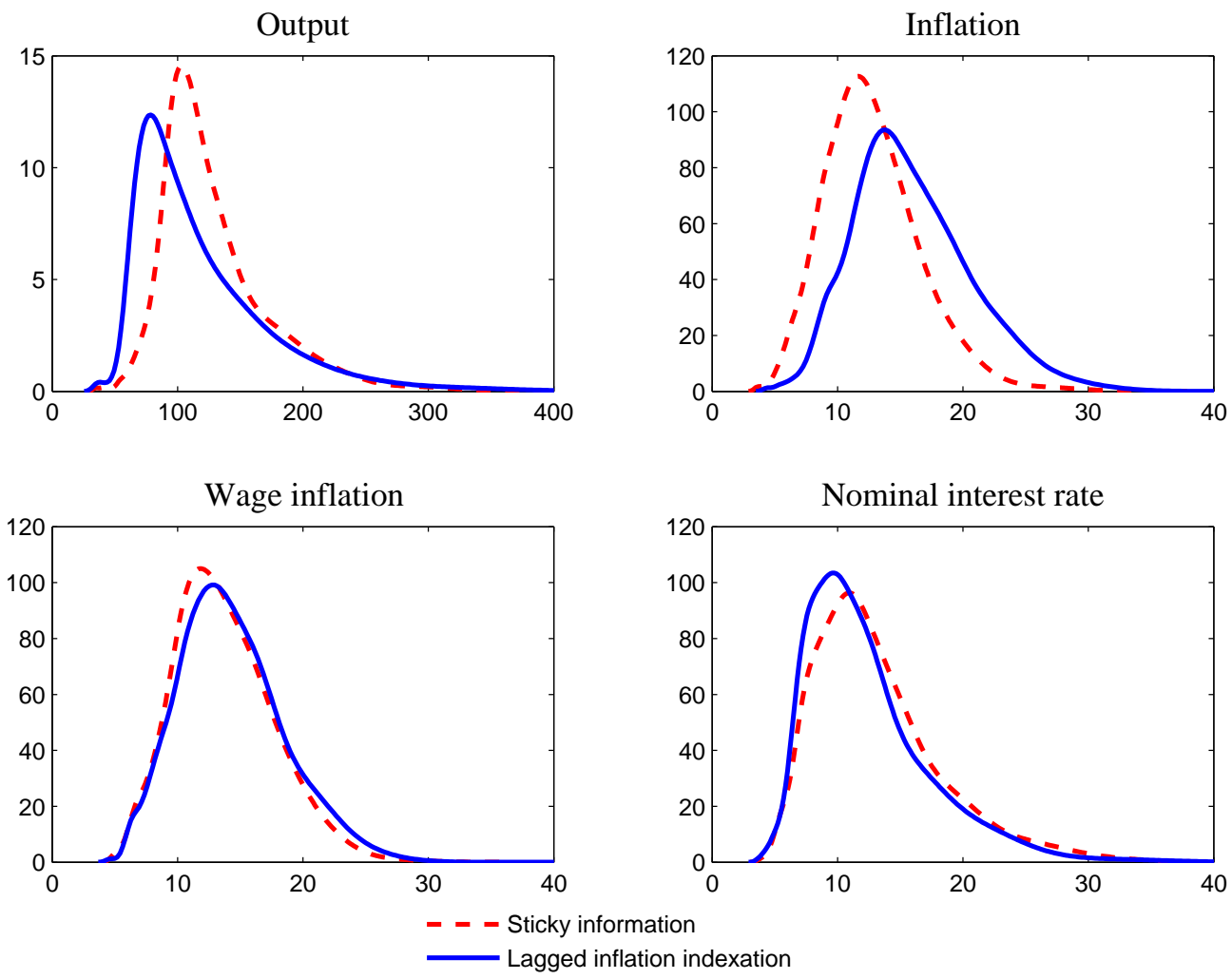
Figure 4: Aggregate responses to a technology shock
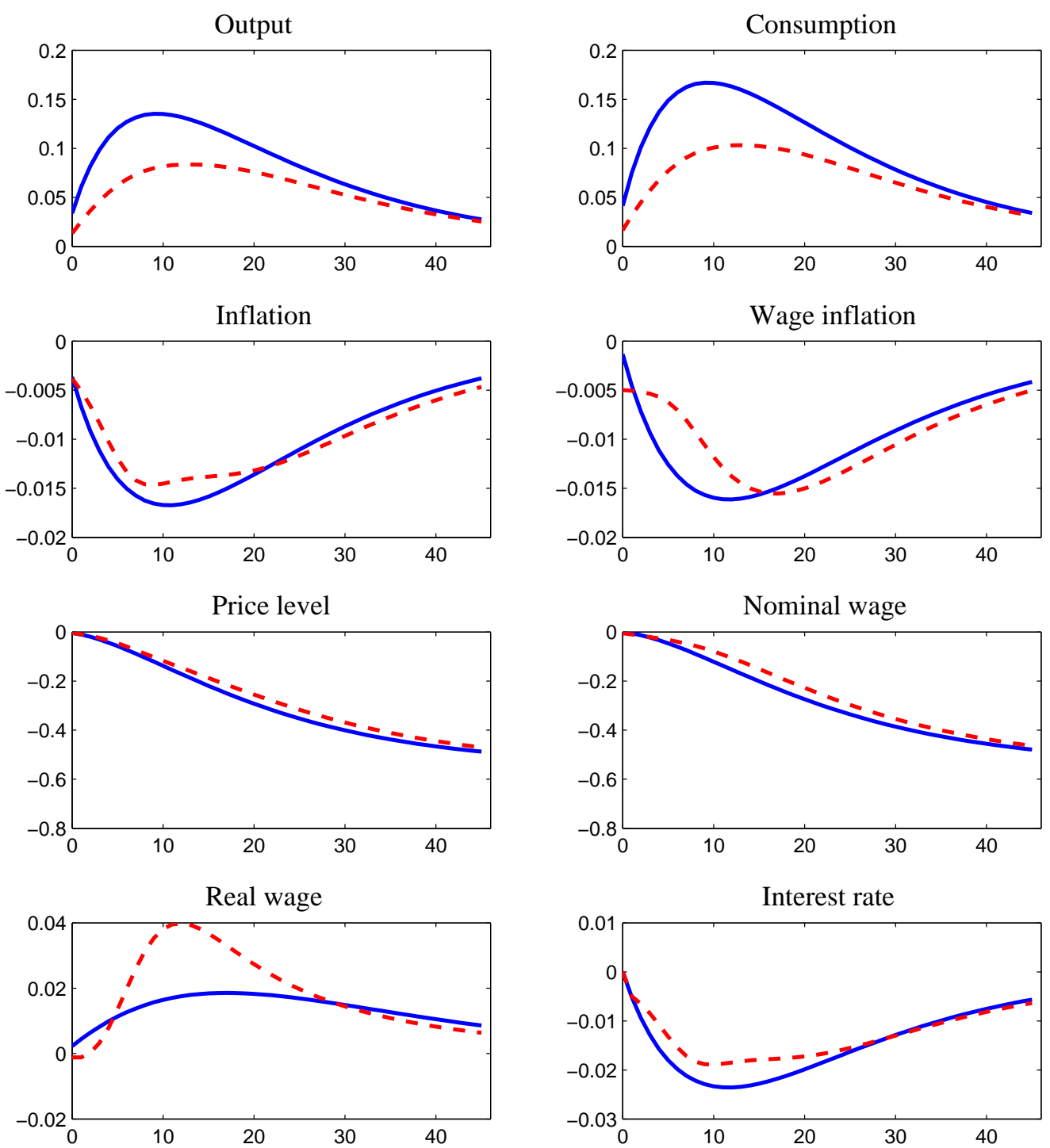

— Lagged inflaiton indexation

- - - Sticky information 
Figure 5: Aggregate responses to a government spending shock
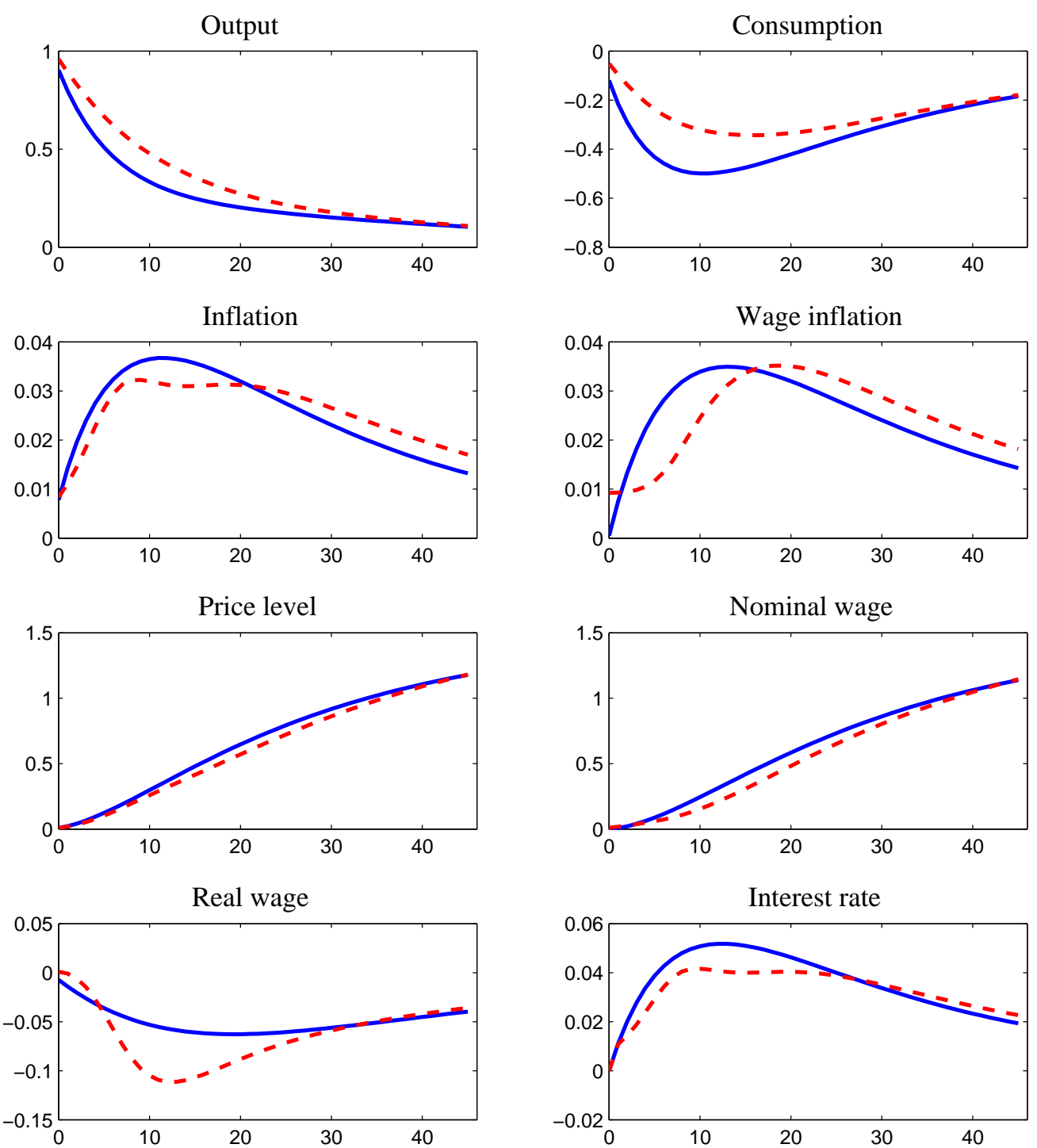

— Lagged inflaiton indexation _ - - Sticky information 
Table 1. Estimated results for the lagged inflation indexation model.

\begin{tabular}{|c|c|c|c|c|c|c|c|c|c|c|}
\hline & $\gamma_{h}$ & $\gamma_{p}$ & $\gamma_{w}$ & $\alpha_{p}$ & $\alpha_{w}$ & $a_{\pi}$ & $a_{y}$ & $\rho_{e}$ & $\sigma_{\nu}$ & $\mathcal{J}_{T}$ \\
\hline Baseline & $\begin{array}{c}.81 \\
(.13) \\
{[.55, .99]}\end{array}$ & $\begin{array}{c}1 \\
(-) \\
{[.78,1]}\end{array}$ & $\begin{array}{c}1 \\
(-) \\
{[0.64,1]}\end{array}$ & $\begin{array}{c}.74 \\
(.19) \\
{[.22, .89]}\end{array}$ & $\begin{array}{c}.84 \\
(.11) \\
{[.61, .99]}\end{array}$ & $\begin{array}{c}1.41 \\
(-) \\
{[1,2.34]}\end{array}$ & $\begin{array}{c}0 \\
(-) \\
{[0, .56]}\end{array}$ & $\begin{array}{c}.92 \\
(.04) \\
{[.83, .98]}\end{array}$ & $\begin{array}{c}.18 \\
(.02) \\
{[.13, .20]}\end{array}$ & $\begin{array}{c}52.09 \\
{[.39]}\end{array}$ \\
\hline $\begin{array}{l}\text { Labor supply } \\
\text { elasticity, } \omega_{w}^{-1}=.1\end{array}$ & $\begin{array}{c}.82 \\
(.13) \\
{[.54, .99]}\end{array}$ & $\begin{array}{c}.98 \\
(-) \\
{[.71,1]}\end{array}$ & $\begin{array}{c}1 \\
(-) \\
{[0.61,1]}\end{array}$ & $\begin{array}{c}.77 \\
(.21) \\
{[.22, .89]}\end{array}$ & $\begin{array}{c}.77 \\
(.15) \\
{[.13, .93]}\end{array}$ & $\begin{array}{c}1.42 \\
(-) \\
{[1,2.24]}\end{array}$ & $\begin{array}{c}0 \\
(-) \\
{[0, .95]}\end{array}$ & $\begin{array}{c}.92 \\
(.04) \\
{[.81, .98]}\end{array}$ & $\begin{array}{c}.18 \\
(.02) \\
{[.13, .20]}\end{array}$ & $\begin{array}{c}51.63 \\
{[.38]}\end{array}$ \\
\hline Risk aversion, $\sigma=.5$ & $\begin{array}{c}.88 \\
(.09) \\
{[.70, .99]}\end{array}$ & $\begin{array}{c}1 \\
(-) \\
{[.80,1]}\end{array}$ & $\begin{array}{c}1 \\
(-) \\
{[0.65,1]}\end{array}$ & $\begin{array}{c}.77 \\
(.18) \\
{[.27, .88]}\end{array}$ & $\begin{array}{c}.81 \\
(.13) \\
{[.57, .99]}\end{array}$ & $\begin{array}{c}1.43 \\
(-) \\
{[1,2.14]}\end{array}$ & $\begin{array}{c}0 \\
(-) \\
{[0, .20]}\end{array}$ & $\begin{array}{c}.91 \\
(.06) \\
{[.81, .97]}\end{array}$ & $\begin{array}{c}.18 \\
(.02) \\
{[.13, .20]}\end{array}$ & $\begin{array}{c}48.77 \\
{[.42]}\end{array}$ \\
\hline $\begin{array}{l}\text { Dixit-Stiglitz } \\
\text { aggregator, } \epsilon_{\mu}=0\end{array}$ & $\begin{array}{c}.82 \\
(.14) \\
{[.55, .99]}\end{array}$ & $\begin{array}{c}1 \\
(-) \\
{[.80,1]}\end{array}$ & $\begin{array}{c}1 \\
(-) \\
{[0.65,1]}\end{array}$ & $\begin{array}{c}.87 \\
(.21) \\
{[.32, .94]}\end{array}$ & $\begin{array}{c}.84 \\
(.13) \\
{[.58, .99]}\end{array}$ & $\begin{array}{c}1.41 \\
(-) \\
{[1,2.14]}\end{array}$ & $\begin{array}{c}0 \\
(-) \\
{[0, .20]}\end{array}$ & $\begin{array}{c}.92 \\
(.08) \\
{[.80, .97]}\end{array}$ & $\begin{array}{c}.18 \\
(.02) \\
{[.13, .20]}\end{array}$ & $\begin{array}{l}52.09 \\
{[.39]}\end{array}$ \\
\hline $\begin{array}{l}\text { Linear production } \\
\text { function, } \phi=1\end{array}$ & $\begin{array}{c}.81 \\
(.14) \\
{[.55, .99]}\end{array}$ & $\begin{array}{c}1 \\
(-) \\
{[.56,1]}\end{array}$ & $\begin{array}{c}1 \\
(-) \\
{[0.65,1]}\end{array}$ & $\begin{array}{c}.42 \\
(.25) \\
{[0, .83]}\end{array}$ & $\begin{array}{c}.85 \\
(.11) \\
{[.60, .67]}\end{array}$ & $\begin{array}{c}1.39 \\
(-) \\
{[1,2.44]}\end{array}$ & $\begin{array}{c}0 \\
(-) \\
{[0, .16]}\end{array}$ & $\begin{array}{c}.91 \\
(.05) \\
{[.82, .98]}\end{array}$ & $\begin{array}{c}.18 \\
(.02) \\
{[.12, .20]}\end{array}$ & $\begin{array}{c}52.36 \\
{[.40]}\end{array}$ \\
\hline CBO output gap & $\begin{array}{c}.88 \\
(.09) \\
{[.67, .98]}\end{array}$ & $\begin{array}{c}1 \\
(-) \\
{[.89,1]}\end{array}$ & $\begin{array}{c}1 \\
(-) \\
{[0.52,1]}\end{array}$ & $\begin{array}{c}.74 \\
(.14) \\
{[.48, .85]}\end{array}$ & $\begin{array}{c}.77 \\
(.12) \\
{[.54, .98]}\end{array}$ & $\begin{array}{c}1.47 \\
(-) \\
{[1,2.27]}\end{array}$ & $\begin{array}{c}0 \\
(-) \\
{[0, .51]}\end{array}$ & $\begin{array}{c}.92 \\
(.04) \\
{[.83, .97]}\end{array}$ & $\begin{array}{c}.17 \\
(.02) \\
{[.13, .20]}\end{array}$ & $\begin{array}{l}63.55 \\
{[.25]}\end{array}$ \\
\hline $\begin{array}{l}\text { Alternative VAR ident., } \\
\text { fed funds rate moves first }\end{array}$ & $\begin{array}{c}.90 \\
(.11) \\
{[.64, .97]}\end{array}$ & $\begin{array}{c}1 \\
(-) \\
{[.63,1]}\end{array}$ & $\begin{array}{c}1 \\
(-) \\
{[0.63,1]}\end{array}$ & $\begin{array}{c}.84 \\
(.14) \\
{[.51, .95]}\end{array}$ & $\begin{array}{c}.90 \\
(.11) \\
{[.66, .99]}\end{array}$ & $\begin{array}{c}1.84 \\
(-) \\
{[1,2.47]}\end{array}$ & $\begin{array}{c}0 \\
(-) \\
{[0, .30]}\end{array}$ & $\begin{array}{c}.94 \\
(.04) \\
{[.85, .97]}\end{array}$ & $\begin{array}{c}.19 \\
(.02) \\
{[.14, .22]}\end{array}$ & $\begin{array}{c}84.62 \\
{[.14]}\end{array}$ \\
\hline
\end{tabular}

Note : The standard deviation of the parameter estimate is shown in parenthesis, and the 90 per cent confidence interval is in brackets. When these measures are not provided, an interval starting at one of the extremes of the parameter space and ending at its 80 percentile is shown in brackets. For the $\mathcal{J}_{T}$ statistic, the p-value of the null $\mathcal{J}_{T}=0$ is shown in brackets. 
Table 2. Estimated results for the sticky information model

\begin{tabular}{|c|c|c|c|c|c|c|c|c|c|c|}
\hline & $\gamma_{h}$ & $\gamma_{p}$ & $\gamma_{w}$ & $\alpha_{p}$ & $\alpha_{w}$ & $a_{\pi}$ & $a_{y}$ & $\rho_{e}$ & $\sigma_{\nu}$ & $\mathcal{J}_{T}$ \\
\hline Baseline & $\begin{array}{c}.90 \\
(.10) \\
{[.64, .98]}\end{array}$ & $\begin{array}{c}.66 \\
(.11) \\
{[.53, .78]}\end{array}$ & $\begin{array}{c}.79 \\
(.23) \\
{[.32, .99]}\end{array}$ & $\begin{array}{c}0 \\
(-) \\
{[0, .32]}\end{array}$ & $\begin{array}{c}0 \\
(-) \\
{[0, .75]}\end{array}$ & $\begin{array}{c}1.29 \\
(-) \\
{[1,2.81]}\end{array}$ & $\begin{array}{c}0 \\
(-) \\
{[0, .08]}\end{array}$ & $\begin{array}{c}.91 \\
(0.04) \\
{[0.83,0.97]}\end{array}$ & $\begin{array}{c}.17 \\
(.02) \\
{[.12, .20]}\end{array}$ & $\begin{array}{c}62.53 \\
{[.26]}\end{array}$ \\
\hline $\begin{array}{l}\text { Labor supply } \\
\text { elasticity, } \omega_{w}^{-1}=.1\end{array}$ & $\begin{array}{c}.89 \\
(.10) \\
{[.64, .98]}\end{array}$ & $\begin{array}{c}.71 \\
(.14) \\
{[.42, .81]}\end{array}$ & $\begin{array}{c}.75 \\
(.20) \\
{[0.35, .99]}\end{array}$ & $\begin{array}{c}.44 \\
(-) \\
{[0, .47]}\end{array}$ & $\begin{array}{c}0 \\
(-) \\
{[0, .69]}\end{array}$ & $\begin{array}{c}1.47 \\
(-) \\
{[1,2.67]}\end{array}$ & $\begin{array}{c}0 \\
(-) \\
{[0, .07]}\end{array}$ & $\begin{array}{c}.92 \\
(.04) \\
{[.84, .97]}\end{array}$ & $\begin{array}{c}.17 \\
(.02) \\
{[.12, .19]}\end{array}$ & $\begin{array}{c}62.04 \\
{[.28]}\end{array}$ \\
\hline Risk aversion, $\sigma=.5$ & $\begin{array}{c}.95 \\
(.05) \\
{[.82, .99]}\end{array}$ & $\begin{array}{c}.69 \\
(.10) \\
{[.58, .78]}\end{array}$ & $\begin{array}{c}.78 \\
(.24) \\
{[.29, .99]}\end{array}$ & $\begin{array}{c}0 \\
(-) \\
{[0, .13]}\end{array}$ & $\begin{array}{c}0 \\
(-) \\
{[0, .75]}\end{array}$ & $\begin{array}{c}1.39 \\
(-) \\
{[1,2.66]}\end{array}$ & $\begin{array}{c}0 \\
(-) \\
{[0, .08]}\end{array}$ & $\begin{array}{c}.92 \\
(.04) \\
{[.83, .97]}\end{array}$ & $\begin{array}{c}.17 \\
(.02) \\
{[.12, .19]}\end{array}$ & $\begin{array}{c}62.40 \\
{[.26]}\end{array}$ \\
\hline $\begin{array}{l}\text { Dixit-Stiglitz } \\
\text { aggregator, } \epsilon_{\mu}=0\end{array}$ & $\begin{array}{c}.90 \\
(.09) \\
{[.67, .98]}\end{array}$ & $\begin{array}{c}.82 \\
(.12) \\
{[.60, .86]}\end{array}$ & $\begin{array}{c}.76 \\
(.20) \\
{[.35, .99]}\end{array}$ & $\begin{array}{c}0 \\
(-) \\
{[0, .43]}\end{array}$ & $\begin{array}{c}0 \\
(-) \\
{[0, .76]}\end{array}$ & $\begin{array}{c}1.29 \\
(-) \\
{[1,2.90]}\end{array}$ & $\begin{array}{c}0 \\
(-) \\
{[0, .28]}\end{array}$ & $\begin{array}{c}.91 \\
(.04) \\
{[.83, .97]}\end{array}$ & $\begin{array}{c}.17 \\
(.02) \\
{[.12, .20]}\end{array}$ & $\begin{array}{c}61.79 \\
{[.28]}\end{array}$ \\
\hline $\begin{array}{l}\text { Linear production } \\
\text { function, } \phi=1\end{array}$ & $\begin{array}{c}.90 \\
(.10) \\
{[.64, .98]}\end{array}$ & $\begin{array}{c}.59 \\
(.15) \\
{[.37, .77]}\end{array}$ & $\begin{array}{c}.78 \\
(.22) \\
{[.32, .99]}\end{array}$ & $\begin{array}{c}0 \\
(-) \\
{[0, .37]}\end{array}$ & $\begin{array}{c}0 \\
(-) \\
{[0, .71]}\end{array}$ & $\begin{array}{c}1.28 \\
(-) \\
{[1,2.75]}\end{array}$ & $\begin{array}{c}0 \\
(-) \\
{[0, .09]}\end{array}$ & $\begin{array}{c}.91 \\
(.04) \\
{[.83, .97]}\end{array}$ & $\begin{array}{c}.17 \\
(.02) \\
{[.12, .19]}\end{array}$ & $\begin{array}{c}61.30 \\
{[.40]}\end{array}$ \\
\hline CBO output gap & $\begin{array}{c}.95 \\
(.06) \\
{[.79, .99]}\end{array}$ & $\begin{array}{c}.62 \\
(.12) \\
{[.48, .78]}\end{array}$ & $\begin{array}{c}.77 \\
(.25) \\
{[.28, .99]}\end{array}$ & $\begin{array}{c}0 \\
(-) \\
{[0, .26]}\end{array}$ & $\begin{array}{c}0 \\
(-) \\
{[0, .77]}\end{array}$ & $\begin{array}{c}1.56 \\
(-) \\
{[1,3.09]}\end{array}$ & $\begin{array}{c}0 \\
(-) \\
{[0, .15]}\end{array}$ & $\begin{array}{c}.93 \\
(.04) \\
{[.84, .97]}\end{array}$ & $\begin{array}{c}.17 \\
(.02) \\
{[.12, .19]}\end{array}$ & $\begin{array}{c}75.78 \\
{[.19]}\end{array}$ \\
\hline $\begin{array}{l}\text { Alternative VAR ident., } \\
\text { fed funds rate moves first }\end{array}$ & $\begin{array}{c}.95 \\
(.09) \\
{[.72, .99]}\end{array}$ & $\begin{array}{c}.77 \\
(.15) \\
{[.48, .86]}\end{array}$ & $\begin{array}{c}.84 \\
(.25) \\
{[.34, .99]}\end{array}$ & $\begin{array}{c}0 \\
(-) \\
{[0, .45]}\end{array}$ & $\begin{array}{c}.12 \\
(-) \\
{[0, .77]}\end{array}$ & $\begin{array}{c}1.38 \\
(-) \\
{[1,3.89]}\end{array}$ & $\begin{array}{c}0 \\
(-) \\
{[0, .08]}\end{array}$ & $\begin{array}{c}.93 \\
(.04) \\
{[.87, .98]}\end{array}$ & $\begin{array}{c}.19 \\
(.02) \\
{[.14, .22]}\end{array}$ & $\begin{array}{c}85.44 \\
{[.11]}\end{array}$ \\
\hline $\begin{array}{l}\text { Attentive consumers and } \\
\text { workers, } \gamma_{h}=\gamma_{w}=0\end{array}$ & 0 & $\begin{array}{c}.60 \\
(.11) \\
{[.49, .72]}\end{array}$ & 0 & $\begin{array}{c}.31 \\
(-) \\
{[.0, .41]}\end{array}$ & $\begin{array}{c}.54 \\
(.18) \\
{[.27, .85]}\end{array}$ & $\begin{array}{c}4.36 \\
(-) \\
{[1.53,5]}\end{array}$ & $\begin{array}{c}.06 \\
(-) \\
{[0, .09]}\end{array}$ & $\begin{array}{c}.98 \\
(.08) \\
{[.72, .99]}\end{array}$ & $\begin{array}{c}.17 \\
(.02) \\
{[.12, .18]}\end{array}$ & $\begin{array}{c}267.57 \\
{[.02]}\end{array}$ \\
\hline $\begin{array}{l}\text { Attentive workers, } \\
\gamma_{w}=0\end{array}$ & $\begin{array}{c}.89 \\
(.10) \\
{[.67, .99]}\end{array}$ & $\begin{array}{c}.78 \\
(.11) \\
{[.62, .87]}\end{array}$ & 0 & $\begin{array}{c}.09 \\
(-) \\
{[.0, .67]}\end{array}$ & $\begin{array}{c}0.63 \\
(.16) \\
{[.34, .88]}\end{array}$ & $\begin{array}{c}1.78 \\
(-) \\
{[1,3.11]}\end{array}$ & $\begin{array}{c}.08 \\
(-) \\
{[0, .20]}\end{array}$ & $\begin{array}{c}.94 \\
(.04) \\
{[.85, .99]}\end{array}$ & $\begin{array}{c}.17 \\
(.02) \\
{[.12, .19]}\end{array}$ & $\begin{array}{c}199.33 \\
{[.11]}\end{array}$ \\
\hline $\begin{array}{l}\text { Attentive firms, } \\
\gamma_{p}=0\end{array}$ & $\begin{array}{c}.95 \\
(.06) \\
{[.81, .99]} \\
\end{array}$ & 0 & $\begin{array}{c}.79 \\
(.19) \\
{[.16, .85]} \\
\end{array}$ & $\begin{array}{c}.04 \\
(-) \\
{[0, .33]}\end{array}$ & $\begin{array}{c}0.29 \\
(-) \\
{[0, .74]}\end{array}$ & $\begin{array}{c}1.09 \\
(-) \\
{[1,2.58]}\end{array}$ & $\begin{array}{c}0 \\
(-) \\
{[0, .27]}\end{array}$ & $\begin{array}{c}.90 \\
(.05) \\
{[.82, .98]} \\
\end{array}$ & $\begin{array}{c}.18 \\
(.02) \\
{[.13, .21]} \\
\end{array}$ & $\begin{array}{c}105.85 \\
{[.09]}\end{array}$ \\
\hline
\end{tabular}

Note : The standard deviation of the parameter estimate is shown in parenthesis, and the 90 per cent confidence interval is in brackets. When these measures are not provided, an interval starting at one of the extremes of the parameter space and ending at its 80 percentile is shown in brackets. For the $\mathcal{J}_{T}$ statistic, the p-value of the null $\mathcal{J}_{T}=0$ is shown in brackets. 
Table 3. Goodness of fit, in terms of the RMSE* 1000

\begin{tabular}{|c|c|c|c|c|c|c|c|c|}
\hline & \multicolumn{4}{|c|}{ Sticky information } & \multicolumn{4}{|c|}{ Lagged inflation indexation } \\
\hline & $y_{t}$ & $\pi_{t}$ & $\pi_{t}^{w}$ & $i_{t}$ & $y_{t}$ & $\pi_{t}$ & $\pi_{t}^{w}$ & $i_{t}$ \\
\hline Baseline & $\begin{array}{c}103.7 \\
{[78,217]}\end{array}$ & $\begin{array}{c}11.7 \\
{[7,20]}\end{array}$ & $\begin{array}{c}11.8 \\
{[8,21]}\end{array}$ & $\begin{array}{c}10.9 \\
{[7,24]}\end{array}$ & $\begin{array}{c}78.6 \\
{[60,229]}\end{array}$ & $\begin{array}{c}13.8 \\
{[9,25]}\end{array}$ & $\begin{array}{c}12.7 \\
{[8,22]}\end{array}$ & $\begin{array}{c}9.7 \\
{[6,22]}\end{array}$ \\
\hline $\begin{array}{l}\text { Labor supply } \\
\text { elasticity, } \omega_{w}^{-1}=.1\end{array}$ & $\begin{array}{c}95.5 \\
{[71,215]}\end{array}$ & $\begin{array}{l}12.6 \\
{[8,20]}\end{array}$ & $\begin{array}{c}12.2 \\
{[7,20]}\end{array}$ & $\begin{array}{l}10.8 \\
{[7,23]}\end{array}$ & $\begin{array}{c}80.0 \\
{[60,225]}\end{array}$ & $\begin{array}{c}14.0 \\
{[9,25]}\end{array}$ & $\begin{array}{c}12.9 \\
{[8,23]}\end{array}$ & $\begin{array}{c}9.3 \\
{[6,22]}\end{array}$ \\
\hline Risk aversion, $\sigma=.5$ & $\begin{array}{c}101.2 \\
{[77,213]}\end{array}$ & $\begin{array}{c}11.7 \\
{[7,20]}\end{array}$ & $\begin{array}{c}11.9 \\
{[8,21]}\end{array}$ & $\begin{array}{l}11.7 \\
{[7,23]}\end{array}$ & $\begin{array}{c}73.1 \\
{[59,236]}\end{array}$ & $\begin{array}{c}13.6 \\
{[9,24]}\end{array}$ & $\begin{array}{l}13.05 \\
{[8,22]}\end{array}$ & $\begin{array}{c}10.8 \\
{[7,24]}\end{array}$ \\
\hline $\begin{array}{l}\text { Dixit-Stiglitz } \\
\text { aggregator, } \epsilon_{\mu}=0\end{array}$ & $\begin{array}{c}100.0 \\
{[78,218]}\end{array}$ & $\begin{array}{c}13.1 \\
{[8,22]}\end{array}$ & $\begin{array}{c}11.9 \\
{[8,21]}\end{array}$ & $\begin{array}{l}10.3 \\
{[6,23]}\end{array}$ & $\begin{array}{c}77.1 \\
{[60,233]}\end{array}$ & $\begin{array}{l}14.0 \\
{[9,26]}\end{array}$ & $\begin{array}{c}12.3 \\
{[8,23]}\end{array}$ & $\begin{array}{c}9.4 \\
{[6,24]}\end{array}$ \\
\hline $\begin{array}{l}\text { Linear production } \\
\text { function, } \phi=1\end{array}$ & $\begin{array}{c}99.5 \\
{[75,216]}\end{array}$ & $\begin{array}{l}11.8 \\
{[7,19]}\end{array}$ & $\begin{array}{l}11.9 \\
{[8,21]}\end{array}$ & $\begin{array}{l}10.4 \\
{[7,24]}\end{array}$ & $\begin{array}{c}79.8 \\
{[61,237]}\end{array}$ & $\begin{array}{c}13.4 \\
{[9,26]}\end{array}$ & $\begin{array}{c}12.2 \\
{[8,23]}\end{array}$ & $\begin{array}{c}9.4 \\
{[6,26]}\end{array}$ \\
\hline CBO output gap & $\begin{array}{c}76.6 \\
{[60,148]}\end{array}$ & $\begin{array}{c}12.4 \\
{[7,20]}\end{array}$ & $\begin{array}{c}11.7 \\
{[8,20]}\end{array}$ & $\begin{array}{l}11.0 \\
{[7,22]}\end{array}$ & $\begin{array}{c}64.0 \\
{[54,140]}\end{array}$ & $\begin{array}{c}14.5 \\
{[9,24]}\end{array}$ & $\begin{array}{c}12.7 \\
{[8,22]}\end{array}$ & $\begin{array}{c}11.6 \\
{[7,22]}\end{array}$ \\
\hline $\begin{array}{l}\text { Alternative VAR ident., } \\
\text { fed funds rate moves first }\end{array}$ & $\begin{array}{c}130.5 \\
{[93,240]}\end{array}$ & $\begin{array}{c}22.2 \\
{[15,34]}\end{array}$ & $\begin{array}{c}17.0 \\
{[11,27]}\end{array}$ & $\begin{array}{l}11.2 \\
{[8,23]}\end{array}$ & $\begin{array}{c}114.2 \\
{[76,223]}\end{array}$ & $\begin{array}{c}25.6 \\
{[18,40]}\end{array}$ & $\begin{array}{c}16.8 \\
{[12,28]}\end{array}$ & $\begin{array}{l}11.0 \\
{[8,26]}\end{array}$ \\
\hline $\begin{array}{l}\text { Attentive consumers and } \\
\text { workers, } \gamma_{h}=\gamma_{w}=0\end{array}$ & $\begin{array}{c}160.1 \\
{[93,279]}\end{array}$ & $\begin{array}{c}17.7 \\
{[12,32]}\end{array}$ & $\begin{array}{c}21.1 \\
{[14,35]}\end{array}$ & $\begin{array}{c}25.1 \\
{[16,45]}\end{array}$ & - & - & - & - \\
\hline $\begin{array}{l}\text { Attentive workers, } \\
\gamma_{w}=0\end{array}$ & $\begin{array}{c}122.9 \\
{[82,237]}\end{array}$ & $\begin{array}{c}13.5 \\
{[8,21]}\end{array}$ & $\begin{array}{c}26.0 \\
{[14,40]}\end{array}$ & $\begin{array}{l}12.0 \\
{[7,25]}\end{array}$ & - & - & - & - \\
\hline $\begin{array}{l}\text { Attentive firms, } \\
\gamma_{p}=0\end{array}$ & $\begin{array}{r}127.0 \\
{[86,236]}\end{array}$ & $\begin{array}{c}17.4 \\
{[12,28]}\end{array}$ & $\begin{array}{r}11.4 \\
{[7,21]} \\
\end{array}$ & $\begin{array}{r}11.5 \\
{[9,24]} \\
\end{array}$ & - & - & - & - \\
\hline
\end{tabular}

Note : The 90 per cent confidence interval around the median of the root mean squared error is shown in brackets. 
Table 4. Selected estimations of Sticky information.

\begin{tabular}{|c|c|c|c|c|c|c|c|}
\hline & \multicolumn{2}{|c|}{ Eq. framework } & \multicolumn{3}{|c|}{ Do the authors compare to .... ? } & \multirow[b]{2}{*}{ Quantitative method } & \multirow[b]{2}{*}{$\begin{array}{l}\text { Quarters between info.updates } \\
\text { \{firms, workers, households }\end{array}$} \\
\hline & $\begin{array}{l}\text { General. } \\
\text { Pervasive? }\end{array}$ & Partial & Sticky Prices & Inflation index & Dual stickiness & & \\
\hline Andrés et al. (2005) & $\sqrt{ }$ & & & $\sqrt{ }$ & & Maximum likelihood & $\{6.7,-,-\}$ \\
\hline $\begin{array}{l}\text { Coibion and } \\
\text { Gorodnichenko }(2009)^{18}\end{array}$ & $\begin{array}{l}\sqrt{ } \\
\text { No }\end{array}$ & & $\sqrt{ }$ & $\sqrt{ }$ & $\sqrt{ }$ & $\begin{array}{c}\text { MDE on } \\
\text { sample covariances }\end{array}$ & $\{5,-,-\}$ \\
\hline Duport et al. (2008) & & $\sqrt{ }$ & $\sqrt{ }$ & $\sqrt{ }$ & $\sqrt{ }$ & $\begin{array}{l}\text { MDE on } \\
\text { inflation variance }\end{array}$ & $\{1.4,-,-\}$ \\
\hline $\begin{array}{l}\text { Mankiw and } \\
\text { Reis (2006) }\end{array}$ & $\underset{\text { Yes }}{\sqrt{ }}$ & & & & & $\begin{array}{c}\text { MDE on } \\
\text { sample covariances }\end{array}$ & $\{1.9,1.5,2.8\}$ \\
\hline $\begin{array}{l}\text { Mankiw and } \\
\text { Reis (2007) }\end{array}$ & $\underset{\text { Yes }}{\sqrt{ }}$ & & & & & Bayesian & $\{1.4,5.1,5.4\}$ \\
\hline Khan and $\mathrm{Zu}(2006)$ & & $\sqrt{ }$ & & & & $\begin{array}{l}\text { Non-linear LS on } \\
\text { VAR forecasts }\end{array}$ & $\{3$ to $7,-,-\}$ \\
\hline Kiley (2007) & & $\sqrt{ }$ & $\sqrt{ }$ & $\sqrt{ }$ & & Maximum likelihood & $\{1.7,-,-\}$ \\
\hline Korenok (2008) & & $\sqrt{ }$ & $\sqrt{ }$ & & $\sqrt{ }$ & Bayesian & $\{3.3,-,-\}$ \\
\hline Knotek (2008) & & $\sqrt{ }$ & & & $\sqrt{ }$ & $\begin{array}{l}\text { MDE on observed } \\
\text { Phillips curve }\end{array}$ & $\{6.7,-,-\}$ \\
\hline Reis (2009) & $\underset{\text { Yes }}{\sqrt{ }}$ & & & & & Bayesian & $\{1.9,1.4,12.5\}$ \\
\hline Table 2 , row 1 & $\underset{\text { Yes }}{\sqrt{ }}$ & & $\sqrt{ }$ & $\sqrt{ }$ & $\sqrt{ }$ & $\begin{array}{l}\text { MDE on monetary } \\
\text { policy shock }\end{array}$ & $\{3.0,4.8,10.0\}$ \\
\hline
\end{tabular}

\footnotetext{
${ }^{18}$ Coibion and Gorodnichenko (2009) consider a model with four types of firms: pure sticky price, pure sticky information, rule-of-thumb, and flexible-price firms. In their baseline estimation, they found out that pure sticky information firms account for 21 per cent of the total, and that these firms update information on average every 20 quarters. Since 79 per cent of firms gather new information every quarter, the weighted average of information updating is 4.99 quarters.
} 